\title{
LAS YACENTES EPISCOPALES COMO MECANISMOS DE PRONÓSTICO ESCATOLÓGICO. CONTEXTOS TEOLÓGICOS DE LOS SEPULCROS DE JUAN DE ARAGÓN Y ARNAU SESCOMES*
}

\author{
EPISCOPAL RECUMBENTS AS ESCHATOLOGICAL PROGNOSIS MECHANISMS. \\ THEOLOGICAL CONTEXTS OF THE TOMBS OF JUAN DE ARAGÓN \\ AND ARNAU SESCOMES
}

GERARDO BOto VARELA Universitat de Girona; Templa https://orcid.org/0000-0001-5904-5922

Marta SerRano Coll Agregada Serra Hunter-Universitat Rovira i Virgili; Templa https://orcid.org/0000-0001-9077-1359

Resumen: Este artículo razona cómo las esculturas yacentes ad similitudinem de las tumbas episcopales de los siglos XIII y XIV, además de excitar el recuerdo del difunto, visualizaban la condición perceptible que ofrecerían los prelados tras ser elegidos en el Juicio, alcanzar el Cielo y gozar de la visión beatífica. La polémica especulación de que el alma pudiera ver a Dios antes de la reintegración con su cuerpo no fue ajena a la sede de Tarragona en 1330-1350. Las sepulturas monumentales de los arzobispos Juan de Aragón y Arnau Sescomes, implicados en esa deliberación teológica, remiten al pasado tanto como al futuro, multidireccional y simultáneamente.

Palabras clave: Escultura yacente; arzobispos; Visio Dei; prospectiva escatológica; Juan de Aragón; Arnau Sescomes.

Abstract: This article explains how the recumbent sculptures ad similitudinem of $13^{\text {th }}$ - and $14^{\text {th }}$-century episcopal tombs, as well as ensuring the memory of the deceased, depict the perpetual beatific appearance that they would enjoy once they reached Heaven after being chosen on the Day of Judgement. The controversial speculation that the soul would be able to see God before reintegration with its body was not unknown in the See of Tarragona in the period from 1330 to 1350. The monumental tombs of Archbishops Juan de Aragón and Arnau Sescomes, both of whom were involved in this theological debate, refer to the past as much as to the future in simultaneous, multidirectional ways.

Keywords: Recumbent statue; archbishops; Visio Dei; scathological prospective; Juan de Aragón; Arnau Sescomes.

\section{SUMARIO}

1. Preámbulo metodológico.- 2. Retrospección y prospección en las tumbas episcopales (s. XIII-XIV).- 3. La resurrección de los muertos.- 4. Las tumbas de Juan de Aragón y Arnau Sescomes.- 5. Conclusión.- 6. Bibliografía citada.

\footnotetext{
"Esta investigación se enmarca en los proyectos de investigación "Sedes memoriae 2: Memorias de cultos y las artes del altar en las catedrales medievales hispanas" (PID2019-105829GB-I00), financiado por el Ministerio de Ciencia e Innovación y "Edificis i escenaris religiosos medievals a la Corona d'Aragó" (2017 SGR 1724), financiado por AGAUR. Nuestra gratitud a A. García Avilés, V. Lucherini, M. Angheben, C. García de Castro, J. A. Morais y a los evaluadores.

Citation / Cómo citar este artículo: Boto Varela, Gerardo; Serrano Coll, Marta (2021), Las yacentes episcopales como mecanismos de pronóstico escatológico. Contextos teológicos de los sepulcros de Juan de Aragón y Arnau Sescomes, "Anuario de Estudios Medievales" 51/1, pp. 175-207. https://doi.org/10.3989/aem.2021.51.1.06

Copyright: (C) 2021 CSIC. Este es un artículo de acceso abierto distribuido bajo los términos de la licencia de uso y distribución Creative Commons Reconocimiento 4.0 Internacional (CC BY 4.0).
} 


\section{PReÁmbulo METOdológico}

Las tumbas son elocuentes realidades físicas, productos culturales con atribuciones funcionales y simbólicas, en ocasiones provistas de un componente artístico y narrativo, por lo que requieren un análisis antropológico ${ }^{1}$. Las sociedades medievales, como otras, entendieron que los sepulcros excitaban en la audiencia el recuerdo del difunto y la piedad por su alma. La Iglesia protocolizó las ceremonias conmemorativas tanto como las oraciones de intercesión. En buena lid, la mayoría de esos monumentos se formularon como plegarias a la Divinidad que favorecían soteriológicamente al difunto. En su forma, uso y relatos visuales se conjugaron principios de doctrina canónica y disquisición teológica, y contribuyeron a visibilizar las potencias del alma, antes y después de reintegrarse con el cuerpo resucitado ${ }^{2}$, en el Juicio Final y finalmente en el Cielo. Las especulaciones intentaban responder a los interrogantes sobre el destino individual y al sentido histórico de la salvación espiritual, que la ortodoxia cristiana remite a la voluntad del Padre omnisciente. Así, las tumbas cristianas deben ser evaluadas conforme a los criterios teológicos vigentes en su tiempo respectivo.

Desde la Historia del Arte pretendemos un conocimiento sensible de esos productos culturales, aspiramos a desentrañar la intencionalidad de sus promotores y a justificar la causalidad de unas sepulturas e iconografías que dieron expresión perceptible a las formas de concebir la relación entre lo inmanente y lo trascendente. Nuestro objeto de estudio y de experiencia secundaria -la primaria correspondió a los espectadores coetáneos a la obra ${ }^{3}$ - son las visualizaciones de los obispos sobre sus tumbas. Pero, puesto que estas no existirían sin un entramado de dogmas y proposiciones, debemos remitirnos a los debates teológicos, aunque no constituyan el objeto nuclear del razonamiento histórico-artístico. El análisis de los monumentos funerarios medievales es, literalmente, una fenomenología del espíritu.

\section{RETROSPECCIÓN Y PROSPECCIÓN EN LAS TUMBAS EPISCOPALES}

\section{(S. XIII-XIV)}

Desarbolado el Antiguo Régimen, los europeos tienden a leer los sepulcros monumentales como contenedores del cadáver de una persona con

\footnotetext{
${ }^{1}$ Marcoux 2013.

${ }^{2}$ Sobre este oxímoron Bynum 1998, p. 594.

${ }^{3}$ El análisis antropológico de la construcción cultural del period eye en Baxandall 1980; Camille 2000; Givens 2005.
} 
dignidad y linaje. Desempeñando funciones pragmáticas, dimensiones simbólicas y discursos persuasivos (conjugando tipología, materiales, iconografías, textos y heráldica), proclamaban la relevancia del individuo. Dado que la sepultura preservará su cuerpo hasta la convocatoria del Juicio (Apocalipsis 20, 13) y se extinga el tiempo histórico ${ }^{4}$, los autores intelectuales procuraron que generaciones de espectadores intercedieran por el difunto. Las tumbas medievales, como las griegas antes, eran para sus coetáneos artefactos que actuaban simultáneamente en el plano retrospectivo (sobre una historia concluida) y prospectivo (ante la esperanza escatológica del creyente). Los sepulcros están siendo -lo enunciamos en presente continuo- mecanismos que se proyectan 5 - por y con su contenido corporal- hacia el futuro, aunque la lectura de los tiempos complementarios debe efectuarse con precaución ${ }^{6}$.

Puesto que las acciones de una persona determinan su salud espiritual en la Tierra y en su destino final (Apocalipsis 20, 12-13), san Agustín consideró que el alma evalúa todo presente -fugaz, pero dilatado e indivisible- en relación con el pasado y el futuro conforme a premisas tropológicas y analógicas ${ }^{7}$. A su juicio, las tumbas monumentales declaraban la esperanza en la providencia ${ }^{8}$. A partir del Evangelio y del Credo se estableció que el alma requiere del cuerpo para ser y para volver a ser persona. Por ello, el Hiponiense señaló como uno de los signos del Juicio la asistencia de las almas integradas con sus cuerpos resucitados ${ }^{9}$. Guillermo de Auxerre, Hugo de Saint Cher, Alberto Magno, Buenaventura y Tomás de Aquino establecieron esta cuestión mediante el argumento de la unibilitas substantialis ${ }^{10}$. En De Ani$m a^{11}$, el Aquinate reinterpretaba la teoría hilemórfica aristotélica y confería al alma la perfección y su total similitud con Dios ${ }^{12}$. Avanzando en las tesis aún platónicas de Hugo de Saint Cher - el alma no es una persona, sino una parte

\footnotetext{
${ }^{4}$ Agustín, Confesiones, libro XI, cap. 20, cf. 26.

${ }^{5}$ Invocamos la polisemia del término en tres de sus acepciones conforme al Diccionario de la Real Academia Española: 1) Lanzar, dirigir hacia delante o a distancia. 2) Idear, trazar o proponer el plan y los medios para la ejecución de algo. 4) Hacer visible sobre un cuerpo o una superficie la figura o la sombra de otro.

${ }^{6}$ Como propone Klein 1980, pp. 212-213 tras reconsiderar las bases metodológicas de $\mathrm{Pa}$ nofsky. Además, Marcoux 2016.

${ }^{7}$ Entendió el tiempo como una impresión mental que existía en el alma: al presente lo denominó visión, al futuro expectativa, y al pasado memoria, vínculo entre vivos y muertos. $C f$. Suter 1965.

${ }^{8}$ Agustín, Confesiones, libro XI, cap. 28. Sus tesis en Eugyppius, Thesaurus, col. 1021.

9 "Sic animae cum carne aderunt, quas iudicat ipse". Agustín, De Civitate Dei, libro XVIII, cap. 23; Agustín, De la Piedad, pp. 413-475. Cf. Villegas, Villanueva 2014, p. 46.

${ }^{10}$ Bynum 1995a, pp. 1-33, n. 34; 1995b; Bieniak 2010, pp. 19-45.

${ }^{11}$ Chenu 1950, 1959; Calvo 1958; Baschet 1999.

${ }^{12}$ Wicki 1954; Bazan 1983; Tugwell 1990; Vergote 1991; Quinn 1993; Bieniak 2010, pp. 95-117.
} 
de ella afirmón ${ }^{13}$-, santo Tomás sentenció anima non est totus homo et anima mea non est ego ${ }^{14}$, pero porta la forma y la especificidad de mi persona. Sutiles debates ponderaron cómo se reintegrarán los cuerpos, qué materialidad tendrán y cómo se operará la continuidad e individualidad del alma ${ }^{15}$.

Estas cláusulas tuvieron consecuencias plásticas en las tumbas desde el siglo XIII, que cobraron una polisemia infrecuente hasta entonces. Los relieves de los costados relataban rituales comprensibles como intercesiones in perpetuum. Otros motivos sólo podían entenderse como visiones anticipatorias. Pero los discursos retrospectivos y prospectivos no se hallan en todos los sepulcros.

Las yacentes ofrecían la apariencia de un hombre idealmente maduro ${ }^{16}$, sin expresar ningún estado de ánimo. Las tumbas de los prelados Rodrigo Díaz en la catedral de Salamanca o Gonzalo de Hinojosa en la de Burgos, de la reina Urraca López de Haro en Vileña o de la noble Elena de Castro en la sede salmantina, excepcionalmente duplican la representación del personaje, en la cista -foco del oficio fúnebre- y sobre la lauda. En esas obras castellanas los perfiles de ambas efigies son idénticos ${ }^{17}$. Cabría inferir de ello que los túmulos góticos muestran en la tapa la semblanza estilizada del finado cuando fue inhumado, provisto de ropajes y atributos, fijando una estable metonimia entre el contenedor pétreo y el contenido anatómico. Las imágenes sepulcrales acentúan la identidad institucional y espiritual de los difuntos y los exaltan como memoranda ${ }^{18}$. Era el espectador o el celebrante del periodo quien actualizaba desde su experiencia subjetiva -su hic et nunc- la atemporalidad objetiva del sepultado. La audiencia de una tumba episcopal no disponía ${ }^{19}$, obviamente, de un conocimiento extensivo del desarrollo artístico y conceptual de las yacentes como género plástico; pero sí comprendía su trascendente propósito y el beneficio de la proximidad de reliquias. Revisitados periódica y ritualmente, estos enterramientos espoleaban la conciencia histórica y la empatía ante el sepultado.

El sepulcro medieval opera más allá de un presente estático. Las imágenes de las laudas no solo representan la pretérita apariencia física o la preeminencia institucional del obispo. Fueron ejecutadas como prefiguraciones

\footnotetext{
${ }^{13}$ Bieniak 2010, pp. 47-48, 86-89.

${ }^{14}$ In epistolam I ad Corinthios commentaria, 15, 2; Aquino, Opera Omnia, pp. 33-34.

${ }^{15}$ Los debates teológicos sobre cómo perduraba la identidad individual en una continuidad espaciotemporal en Bynum 1990; 1995b, p. 20; Baschet 1999, 2018.

${ }^{16}$ Aunque la primera escultura yacente de un papa, Clemente IV, lo mostraba anciano. Herklotz 2001, pp. 238-241.

${ }^{17}$ No conocemos casos análogos en Navarra, Aragón o Cataluña.

${ }_{18}$ Para Sánchez 2000 la iconografía tumularia confiere dignidad y autoridad al prelado, establece una continuidad histórica de la institución y proporciona memoria colectiva. En las tumbas leonesas aún no se formula cómo será el destino del alma antes y después del Juicio.

${ }^{19}$ Bock, Foletti, Tomasi 2014.
} 
del porvenir escatológico del cuerpo. Las yacentes, “mecanismos" sensibles, se rebelan contra la caducidad carnal y ofrecen una proyección visual ad futurum, esto es, el cuerpo idóneo que aguarda al individuo en la Resurrección, ataviado con las vestiduras y los símbolos de su ordenación y de su funeral. Así se presentará en la convocatoria del Juicio Final, tras despertar (I Tesalonicenses 4, 14) y resurgir del sepulcro (Juan 5, 28-29; Hechos 24, 15; I Corintios 15,12$)$. Ante el interrogante de cómo y con qué cuerpo espiritual volverán los muertos a la vida (I Corintios 15,$35 ; 15,44)$ se resolvió que

resucitarán incorruptibles y nosotros seremos transformados (...) Y cuando este ser corruptible se revista de incorruptibilidad y este ser mortal se revista de inmortalidad, entonces se cumplirá la palabra que está escrita: la muerte ha sido devorada en la victoria (I Corintios 15, 51-53).

Desde el 381 el Credo concluye afirmando Et expecto resurrectionem mortuorum, et vitam venturi seculi ${ }^{20}$.

En los siglos XIII y XIV se dirimió cómo y cuándo se produciría la perpetua experiencia visual de Dios y de los bienaventurados. Los promotores más intelectivos predicaban y advertían la conjugación de tiempos "en", "ante", "sobre" y "tras" las tumbas: el pretérito perfecto en imágenes de obras de misericordia o rituales fúnebres en el frente de la cista o al fondo del arcosolio; el presente continuo en el que el cadáver espera la Parusía; el futuro perfecto al figurar sobre la lauda el aspecto que ofrecerá al salir para asistir al Juicio y el futuro pluscuamperfecto al proyectar la apariencia del cuerpo y las vestiduras restablecidos en la anhelada Gloria, beneficiándose de la visio $D e i^{21}$. Estos dos últimos puntos requieren una justificación.

\section{LA RESURRECCIÓN DE LOS MUERTOS}

El Libro de la Revelación predice que los convocados al Dies Irae (Apocalipsis 11, 18; 20,5) resucitarán con albas blancas (Apocalipsis 6, $11 ; 7,9-14)^{22}$. La especulación de que los muertos saldrán de sus sepulcros con el atuendo que recibieron en el sepelio no tiene base bíblica: es una for-

${ }^{20}$ En la Alta Edad Media se establece que cada uno resucitará con su cuerpo individual. Denzinger 1911, pp. 189, 202-203; fundamental para la primera escolástica, Heinzmann 1965; Cullmann 1969; Van Eijk 1974; Greshake, Kremer 1986, pp. 719-721; Moss 2011.

${ }^{21}$ Cuestión que resuelve la bula Benedictus Deus.

${ }^{22}$ Kosmer 1975 examina los comentarios sobre el Apocalipsis de Teodoro de Mopsuestia, san Gregorio de Nyssa, san Cirilo y san Ambrosio. 
mulación de teología espiritual. El argumento bizantino de la salida de los difuntos se extendió en la Cristiandad latina en pinturas murales y portadas esculpidas desde $1120^{23}$, aunque en el arte español se inauguró en la lauda de Alfonso Ansúrez (1093) ${ }^{24}$. El cuerpo físico del infante Ansúrez defunctus se alza con los ojos abiertos ${ }^{25}$, anhelante y vestido, anticipación mística, más que histórica, de la resurrección corporal del último día, como indicó Moralejo.

Distintas representaciones de los siglos XII y XIII conciben la resurrección con individuos anónimos, desnudos o cubiertos por mortajas o albas blancas: relicario de Saint-Servais de Maastrich, catedral de Laon (fachada oeste), de Reims (transepto norte), de Estrasburgo (fachada oeste), de SaintOmer (portal sur), Tudela (puerta del Juicio), Salterio de la Reina Ingeborg (f. 33r), pinturas de San Román de Toledo... En ocasiones figuran muertos coronados o con vestiduras que revelan su condición institucional y espiritual ${ }^{26}$. En las portadas de Notre-Dame de París ${ }^{27}$ (fig. 1), de Saint Eliphe de Rampillon o de la catedral de Toledo o Tarragona ${ }^{28}$, en las pinturas de Saint-Ambroise de Douadic o la miniatura del Salterio de Marguerite de Bourgogne (f. 19r) los obispos adquieren protagonismo al surgir de sus sepulcros con su atuendo episcopal o, al menos, con la mitra ${ }^{29}$. La Iglesia promovió la conjetura de que los ropajes y los pontificalia con que fueron enterrados resurgirán transmutados envolviendo el cuerpo regenerado ${ }^{30}$. Cabe inferir que los eclesiásticos consideraban que la yacente vaticinaba la apariencia visible y revestida del obispo resucitado. Durante el Juicio Final en cada persona se actualizará la dialéctica desnudo/vestido. La desnudez de los justos será cubierta con la indumentaria de luz concedida por Dios y con ella traspasarán la ianua coeli. En esa circunstancia gloriosa los obispos se presentarán -si no lo habían hecho antes- con sus pontificalia entre los elegidos: códice de Bamberg donado por Enrique II (f. $4 \mathrm{v})^{31}$, fachadas de las catedrales de Ferrara, Amiens o León, pinturas de Burgfelden...

\footnotetext{
${ }^{23}$ Wortley 2001, pp. 57-60; Angheben 2013, pp. 127-295; 2020, p. 155.

${ }^{24}$ Moralejo 1978; Hassig 1991.

${ }^{25}$ Como en el sepulcro de santa Froila (Catedral de Lugo) o los yacentes de Ferran del Soler y Raymond de Villalonga de Elna. Panofsky 1964, p. 61.

${ }^{26}$ En la fachada de Saint-Denis Suger resucita con hábito monacal arrodillado al pie de Cristo.

${ }^{27}$ Estado original en el dibujo de Gilbert. $C f$. Angheben 2013, pp. 543-544.

${ }^{28}$ Angheben 2020.

${ }^{29}$ En el Descensus ad Inferos del Salterio de san Luis y Blanca de Castilla (Paris, Bibliothèque Arsenal, ms. 1186, f. 25v) Cristo rescata, entre otros, a un mitrado.

${ }^{30}$ Sobre ropajes, Miller 2014.

${ }^{31}$ Palazzo 1999, pp. 104-105; Schmitt 2009, pp. 52-54.
} 


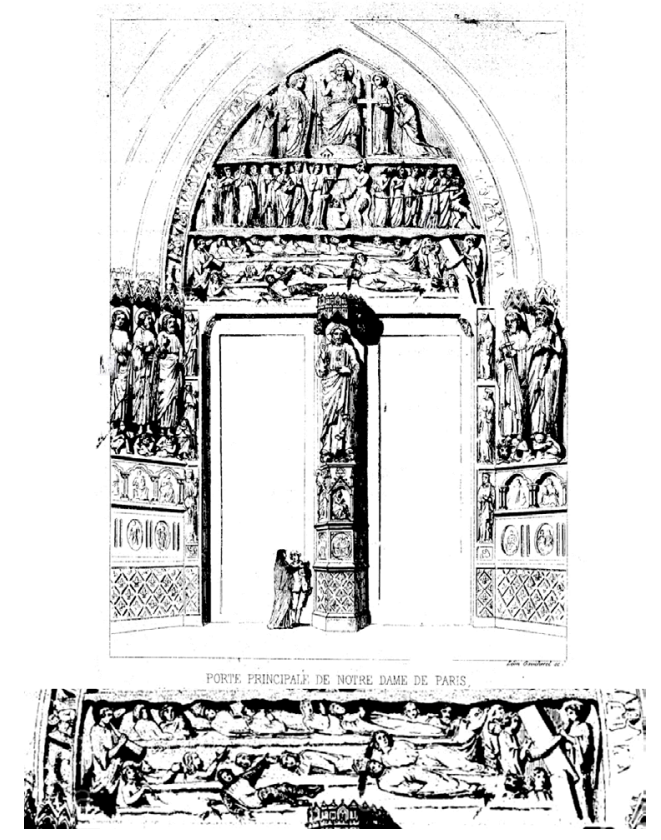

Fig. 1. Viollet-le-Duc y Lassus, Porte principale de Notre Dame de Paris d'après un dessin original fait avant la demolition du trumeau en 177I [de Gilbert], 1843.

Detalle del dintel con tres obispos resucitando, entre un soldado y personajes desnudos (cortesía Boston Public Library).

Desde el siglo XII, la iconografía de la inhumación de los prelados les muestra vestidos con sus atavíos episcopales: miniatura de la Vita Sancti Cuthberti que ilustra el hallazgo en 698 de su cuerpo incorrupto vestido de pontifical (fig. 2) ) $^{32}$, cistas de Rodrigo Díaz o de Gonzalo de Hinojosa, miniaturas del entierro de san Agustín ${ }^{33}$ o de Tomás Becket en su tumba ${ }^{34}$, pintura del taller de Van der Weyden con la exhumación de san Huberto de Lieja ${ }^{35}$, ajuares hallados en sepulturas ${ }^{36}$ y referencias documentales ${ }^{37}$.

${ }^{32}$ Londres, British Library, Yates Thompson, ms. 26, f. 77r. Durham, ca. 1180. Marner 2000, pp. 99 y 105, fig. 42. También los prelados Remigio de Lincoln (1067-1092) o Theobaldo de Canterbury (1139-1161) se hallaron incorruptos.

${ }_{33}^{33}$ Bolonia, 1325-1335. San Petersburgo, Ermitage, ms. 16931, f. 2.

${ }^{34}$ Londres, British Library, ms Royal 2 B VII, f. 298v.

${ }^{35} \mathrm{Ca}$. 1435. Londres, National Gallery, 783.

${ }^{36}$ Véase el de Jiménez de Rada: Bango 2006.

${ }^{37}$ Sobre la muerte de Inocencio III, Paravicini 2000, p. XV, 122. Elocuente, Partida I, título XIII, Ley XIII de Las Siete Partidas de Alfonso X. 


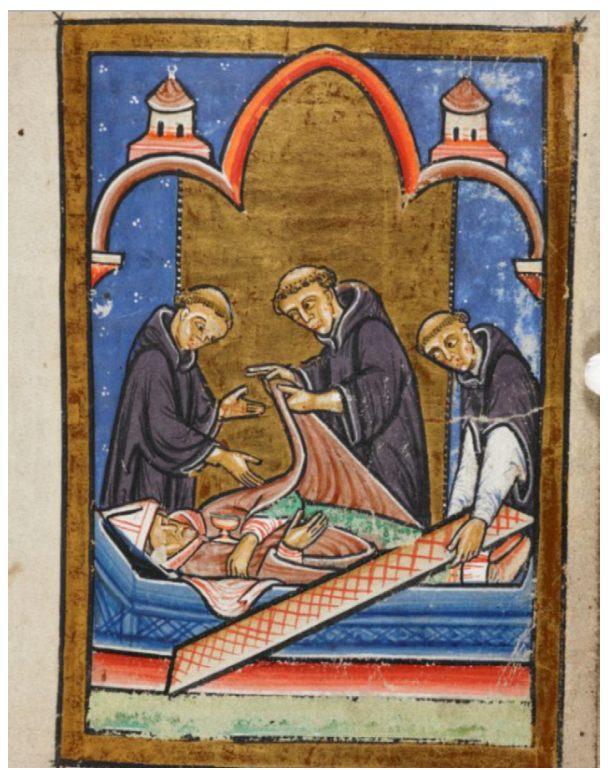

Fig. 2. Vita Sancti Cuthberti, British Library, Yates Thompson ms 26, f. 77r. (C) British Library.

Durante el Medievo evidentemente no solo se enterró vestidos a los prelados $^{38}$. Liturgistas, teólogos y predicadores de los siglos XII y XIII justificaron que antes de la inhumación el cadáver debía exhibirse públicamente con decorosos atavíos e insignias ${ }^{39}$ porque constituían signo de estatus social, vínculo entre la vida terrenal y la celestial y, además, eficaz instrumento de paso a la vida eterna ${ }^{40}$. A la luz de esto, entendemos que los promotores episcopales solicitaron incluir en las iconografías de la resurrección a obispos revestidos de tales. Las yacentes -incisas o tridimensionales- ensalzan una biografía y pronostican los cuerpos refulgentes que ofrecerán en la Gloria ${ }^{41}$, una vez que Dios les recompense con las vestiduras espiritualizadas ${ }^{42}$. Tras superar el jui-

${ }^{38}$ Adhemar de Chabannes, Chronique, vol. II-25, p. 105 acreditó que Carlomagno fue inhumado "Vestitum est corpus ejus indumentis imperinlibus, et sudario sub diademate facies ejus operta est". Callahan 2016, pp. 61-62.

${ }^{39}$ Según Durando, los principales clérigos deben ser enterrados con sus ropas porque designan las virtudes que deben poseer en un alto grado y con ellas presentarse a Dios. Durandus, Rationale, p. 140; Rational, pp. 113-114. Cf. Treffort 2001, p. 354, n. 15.

${ }^{40}$ La Figuration 1989; Treffort 2001, pp. 353-354.

${ }^{41}$ Sobre la escultura como metáfora de la resurrección de la carne, Pereda 2001, pp. 64-66.

${ }^{42}$ Sobre la imposibilidad de entrar desnudo a la Gloria, Chobham, Summa, cap. 6, cf. Treffort 2001, n. 43. 
cio moral, el beneficio de portar los pontificalia opera en los planos visual y estamental ${ }^{43}$ : incorporados a los elegidos, los prelados tendrán la capacidad espiritual de ver a Dios y ser vistos por Él y, al tiempo, ofrecerán una identidad visible ante los demás justos.

Para Jean Beleth o Durando, las vestiduras sacerdotales que los obispos recibirán antes de ingresar en la corte celestial serán ornamentos de virtud y les permitirán ocupar el primer grado de la jerarquía eclesiástica entre los reunidos en torno a Dios ${ }^{44}$. Los liturgistas de los siglos XII-XIV no establecieron doctrina sobre cómo se transmutará la ropa material en atuendos celestiales ${ }^{45}$. Sin embargo, la iconografía medieval atestigua que los obispos ingresarán en el Paraíso con atributos como los que asumieron en su ordenación episcopal, que revistieron su cadáver y que figuran sobre las tumbas. La conclusión es nítida: además de estimular recuerdos y oraciones, las yacentes con sus pontificalia establecen una continuidad causal con la resurrección y presagian la apariencia escatológica del prelado.

Los rostros de los obispos aportan un nuevo indicio para considerar la naturaleza prospectiva de las laudas. A pesar de corresponder a hombres fallecidos con 50, 60 o 75 años, lo habitual es que se les muestre en edad madura, pero no anciana. ¿Es un recurso formal genérico, sin significación específica? Extender el interrogante a las tumbas de los monarcas hispanos puede ayudar a despejar la incógnita. A lo largo de tres siglos, sus yacentes no consideraron la edad del rey al morir. Sin embargo, algunos figuran avejentados en el Libro de los Testamentos, el Tumbo A, el Libro de las Estampas, la Crónica de los Reyes, los Usatges i Constitucions de Catalunya de la Paeria de Lleida o el Tercer Llibre Verd. Aunque se pretendiera una variatio plástica y no representar una fisonomía, se admitió dibujarlos seniles. No sucedió así en sus tumbas. Se optó por concederles el porte de treinta y tres años, conforme al ideal teológico de la edad de Cristo al resucitar ${ }^{46}$. Esa es la que manifestarán los resucitados y con la que perdurarán eternamente. Proyectada esta doctrina a reyes y obispos, los canónigos no advertirían en la yacente un intento de idealizar el semblante del prelado fallecido, sino la prefiguración del rostro idóneo que tendrá tras resucitar el cuerpo, asociarse con su alma, revestirse

${ }^{43}$ Ibidem, pp. 356-357 señala que Guibert de Nogent en Autobiografía consideró que en las tumbas de los prelados indignos se producía una milagrosa disociación de cuerpo y ropajes. Ibidem, p. 359, n. 24-30 señala que Cesáreo de Heisterbach (Dialogus Miraculorum, XI, 3) pronosticó que el estado de la vestimenta en las sepulturas revelaba la situación del alma en el más allá.

${ }^{44}$ Durandus, Rational, p. 114.

${ }^{45}$ Sicard 1978, pp. 314-316; Treffort 2001, n. 41.

${ }^{46}$ Ribot 1729 , p. 116. Sobre las yacentes con los ojos abiertos y el ideal de treinta y tres años, Tummers 1980, pp. 24, 127-128; Paravicini 2003, p. 250. 
con pontificalia y ocupar su posición privilegiada en la órbita de Dios, como ya expuso la miniatura otónida de $c a$. 1000 conservada en Bamberg.

¿Qué son las yacentes bajomedievales? A nuestro juicio, visualizaciones que explicitan cómo aparecerá el cuerpo resucitado y que predicen la consecución de una eterna y gozosa condición visiva y un estatuto visible - ante Dios y el resto de los bienaventurados- ornado por sus virtudes morales.

\section{LAS TUMBAS DE JUAN DE ARAGÓN Y ARNAU SESCOMES}

En la averiguación teológica relativa a la posibilidad de que los justos vean a Dios tras su muerte, el conspicuo arzobispo tarraconense y patriarca de Alejandría Juan de Aragón $(† 19 / 08 / 1334)^{47}$ desempeñó un activo papel junto a autores como Guillermo de Ockham y Bonagrazia de Bérgamo.

Sus tesis exegéticas quedaron cristalizadas en su monumental tum$\mathrm{ba}^{48}$, prestigiada por el uso de mármol níveo levemente veteado. Se ubica en el muro sur del presbiterio mayor de la catedral de Tarragona, bajo el armarium destinado a las reliquias más venerables del templo, la Santa Espina y el brazo de la patrona santa Tecla, que había llegado a la ciudad gracias a la implicación personal del rey Jaime II, padre del arzobispo. La estructura de la obra, cuyo modelo se ha querido ver en Lombardía, Nápoles o Aviñón ${ }^{49}$, remite a una fachada ${ }^{50}$ : su similitud con la de la capilla de Jesús de la Seu Vella de Lérida, que Arnau Sescomes construyó para su enterramiento, es tan significativa como reveladora (fig. 3). Cabe pues, atribuir la autoría intelectual del sepulcro a Sescomes. Como uno de los cuatro albaceas de don $J_{u a n^{51}}$, tuteló la erección del conjunto fúnebre que, además de la retórica visual que ofrecía el mármol, proponía una conjugación instantánea de los

${ }^{47} \mathrm{Al}$ margen de episcopologios y relaciones arzobispales, se ha analizado en Vincke 1930, pp. 127-272; Rivera 1969, pp. 77-79; Avezou 1930; Risco 1926; Janer 1904; Alcoy 2006, p. 98; Torija, 2012, pp. 288-292.

${ }^{48}$ Citamos apenas: Bertaux 1906, pp. 652-654; Manote, Terés 1997; Previtali 1991; Español 2008; Sánchez 2016; Alcoy 2017b; Serrano, Boto 2018, pp. 134-135; Español 2019, con nueva propuesta de autoría.

${ }^{49}$ Entre los referentes, la sepultura de Guglielmo de Longis de Adraria, en Santa Maria Maggiore de Bérgamo y, sobre todo, las de Roberto el Sabio, María de Valois y Carlos de Calabria en Santa Chiara de Nápoles, la de santa Catalina de Austria en San Lorenzo Maggiore o la de María de Hungría en Santa Maria Donnaregina Vecchia. Sobre las similitudes napolitanas Previtali 1991, pp. 93-99.

${ }^{50}$ Serrano, Boto 2018, pp. 135-136.

${ }^{51}$ Conforme a una carta de Alfonso IV sus albaceas fueron Guillem Riquer, Jaspert Folcrà o Fulcarà, Guillem de Planils y el obispo de Lérida (Sescomes): Español 2019, pp. 178-179. Sescomes fue también legatario de otro arzobispo tarraconense, Guillem de Rocabertí: Rius 1930; Santaulària 1985; Serra 2016. 
tres tiempos agustinianos: el pasado (o memoria) al recordar visible y textualmente a un miembro ilustre y venerable de la sede; el presente (o visión) al fomentar plegarias y servir de escenografía en las ceremonias periódicas que más allá de los aniversarios tenían netas connotaciones funerarias, como el Oficio de Tinieblas - para el que dotó luminarias ${ }^{52}-$; y el futuro (o expectativa), al visibilizar lo que sucederá al final de los tiempos a su cuerpo, pero también a su alma desde el momento del óbito.
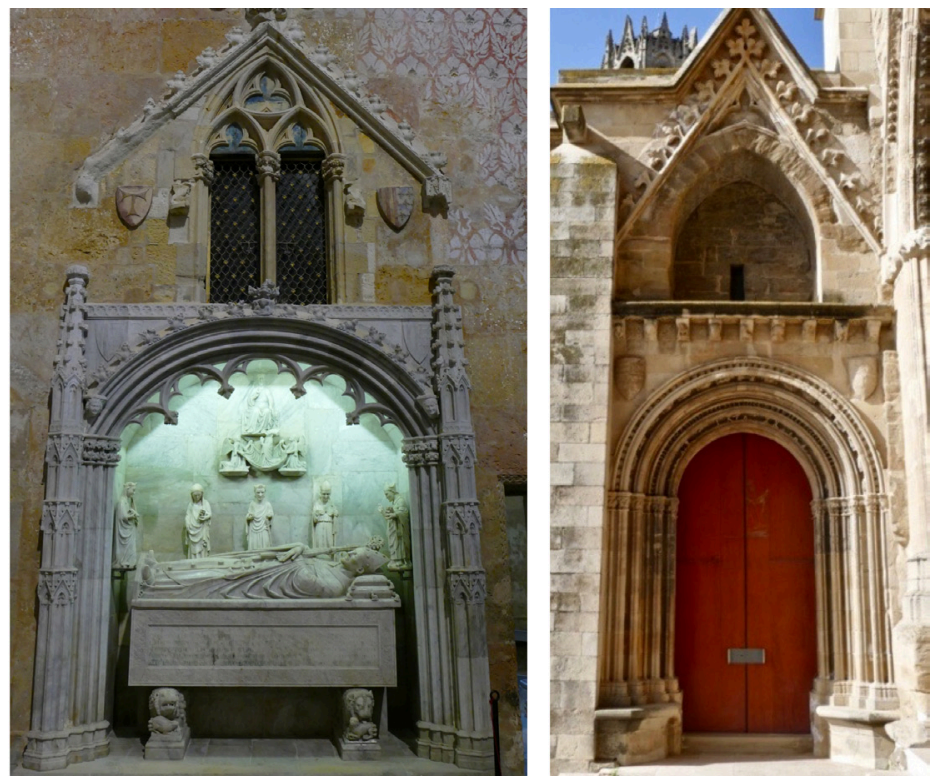

Fig. 3. Izqda. Sepulcro de Juan de Aragón. Drcha. Fachada de la Capilla de Jesús. Catedral de Lérida. Fotos Marta Serrano.

A través del sepulcro de don Juan se comprende mejor cómo explotaron los promotores medievales -y cómo reconocieron los espectadores-el potencial de las imágenes. Ya se ha razonado la capacidad expresiva del mármol veteado en la catedral tarraconense, que en algunos umbrales funcionaba como impelente visual al mismísimo Cielo $^{53}$. Ese significado liminar se intensifica en esta tumba por su composición de portada de capilla, metáfora de la ianua coeli. Su iconicidad es excepcional. Atestigua acontecimientos de la vida del beatífico arzobispo, exalta lo que debe ser rememorado por la

\footnotetext{
${ }^{52}$ Su dotación fue extraordinaria: Sánchez 1954, pp. 101-110; 1955.

${ }^{53}$ Boto 2015.
} 
comunidad canonical, ofrece una visualización de lo que ya experimenta su alma y vaticina su vivencia plena en la Gloria.

La imponente cista despliega una inscripción soberbia por su calidad epigráfica, extensión y contenido ${ }^{54}$ : encomia el abolengo regio del finado, su rápido cursus honorum, sus precoces dotes oratorias, su promoción institucional y artística y acredita su extrema mortificación de la carne ${ }^{55}$. Ensalza su muerte en olor de santidad a los treinta y tres años y los milagros que Dios operó a través de él, en vida y tras su muerte. El elogio de estos méritos beatíficos, con los que se pretendía una inmediata santificación, se ve potenciado por las cualidades plásticas y descriptivas del rostro de su espléndida yacente. En su caso no fue necesario componer un semblante idealizado. La verosimilitud facial se acomoda biológicamente con la edad de Cristo.

Conforme a la práctica funeraria establecida a partir del siglo XII, que requería inhumar a los obispos con sus insignias para el día de la Resurrección, la yacente se exhibe con pontifical. Sobresale la belleza de la pedrería que decora el palio y la mitra, en la que descuella un espléndido camafeo (fig. 4). Otra gema igual ocupa su anillo sigilar, que reivindicaba la antigüedad de la sede y el gusto estético del prelado, acaso heredado de su padre ${ }^{56}$. En la voluta del báculo se labró una Anunciación, tipología habitual pero que no desvinculamos de la mariología profesada por don Juan, quien en uno de sus sermones argumentaba que en la salutación del arcángel Gabriel se manifestaron las tres grandezas de María ${ }^{57}$. La comprensión del alcance teológico y especulativo del sepulcro requiere considerar la sensibilidad espiritual y la actividad homilética del arzobispo ${ }^{58}$.

De acuerdo con los santos que rodean la yacente (Tecla y Fructuoso, vinculados directamente a la sede pero también al prelado ${ }^{59}$, más los santos de su linaje Luis de Anjou $^{60}$, Luis de Francia e Isabel de Hungría), Español y Alcoy coinciden en que este insólito sepulcro reivindica su beata

${ }^{54}$ Transcrita por Villanueva 1851, p. 206.

${ }^{55}$ Contextualización en Bynum 1995a, p. 333.

${ }^{56}$ Consta que Jaime II poseía joyas con esmaltes, cristal, perlas, gemas y camafeos: Martorell 1911-1912. Las evocaciones al pasado romano en Serrano 2018.

${ }^{57}$ En Item in festo Concepcionis: Munté, Tomás 1957, pp. 20-24.

${ }^{58}$ Sobre estos sermones: Catalán 2021. Le agradecemos los diálogos, desde 2017, a propósito del personaje.

${ }^{59}$ La inclinación de don Juan por san Fructuoso se constata por los dos beneficios que instituyó en su honor: Tomás 1960-1961, pp. 41, 45 y doc. 1. Quedó así asociado al primer obispo santo y mártir de la diócesis, cuyo altar se encontraba colindante al muro absidal ante la concavidad axial que suponemos "trono de san Fructuoso", donde los arzobispos recibían su ordenación: Ibidem pp. 54-55.

${ }^{60}$ Alcoy 2017a, pp. 269-272; Horowski 2017. 
stirps, si bien estrecharía también los lazos de la iglesia tarraconense con la monarquía ${ }^{61}$. Esa concordia era imprescindible en una ciudad cuyo gobierno jurisdiccional era compartido por tres poderes contrapuestos ${ }^{62}$. El monumento visibilizaba y reforzaba a través de la iconografía, la heráldica y la inscripción, una deseada cohesión institucional y política.
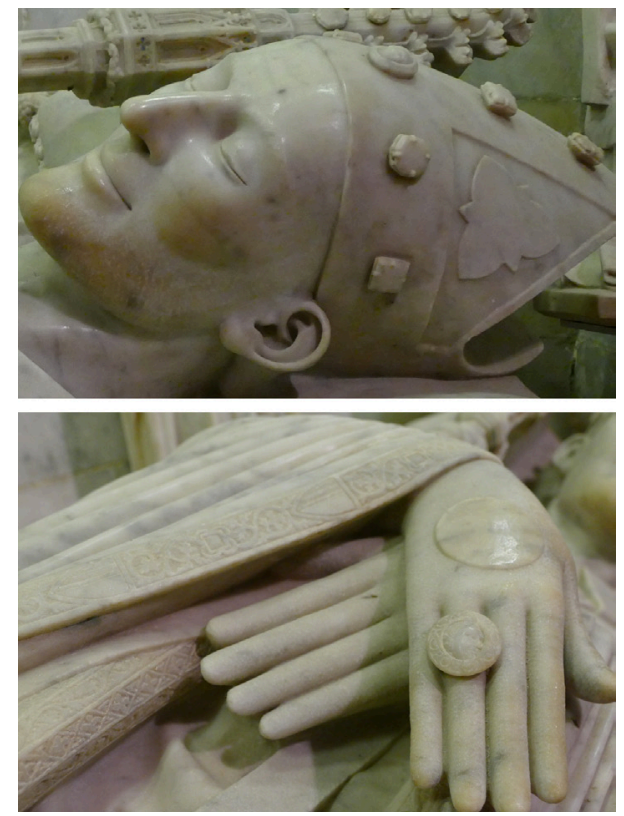

Fig. 4. Detalle de la mitra con pedrería y del anillo sigilar de Juan de Aragón. Foto Marta Serrano.

Entre los sepulcros invocados como referentes, es en el de María de Hungría $(\uparrow 1323)^{63}$ donde advertimos un mayor ascendente conceptual (galería de familiares), aunque no formal o tipológico. Esta soberbia tumba napolitana exhibe el splendor de la casa real, la virtus de la soberana y vigoriza la legitimidad de su hijo Roberto I. Una estructura provista de una camera funebris alberga la yacente de la reina y, en el muro del fondo, dos oficiantes de una conmemoración litúrgica componen una commendatio animae.

\footnotetext{
${ }^{61}$ Español 2008; 2019, pp. 175-181.

${ }^{62}$ Rey, arzobispo y municipalidad. Sobre los conflictos Bonet, Isla 2011; Juncosa 2015. Su eco en la promoción catedralicia: Boto, Serrano 2018.

${ }^{63} \mathrm{Su}$ sepulcro (1325-1326) es del taller de Tino di Camaino y el arquitecto Gagliardo Primario, a instancias de Roberto I: Michalsky 2000, pp. 61-77; Lucherini 2015.
} 
Michalsky ${ }^{64}$, al inaugurar los estudios sobre la beata stirps, advirtió en la visualización de este concepto el aval para lograr la salvación escatológica. Las tres caras visibles de la caja recibieron las efigies de sus once vástagos entronizados, y en el eje de la cista san Luis bendicente, canonizado en 1317. La estructura del monumento funerario tarraconense y sus recursos plásticos difieren por completo del napolitano, aunque ambos incorporan figuras de pie y en pequeño tamaño en el fondo, receta sin precedentes en la escultura gótica catalana (fig. 5) ${ }^{65}$. Más significativo es que ambos loen a sendas personas por sus virtudes morales y su pertenencia a la misma gloriosa estirpe. Esas analogías políticas, institucionales y espirituales se explican por los fecundos vínculos entre las casas de Aragón y de Nápoles.

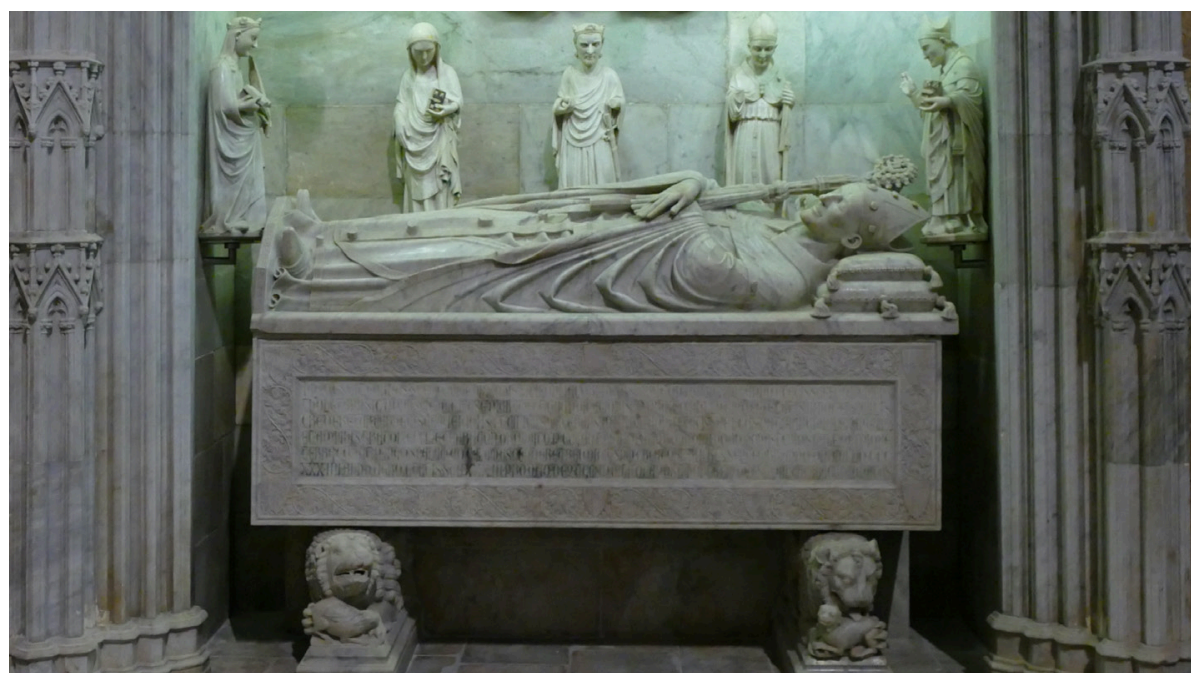

Fig. 5. Yacente de Juan de Aragón con sus santos familiares. Foto Marta Serrano.

La documentación revela que María de Hungría, madre de Blanca de Anjou y abuela materna del patriarca, fue profundamente estimada por Jaime II ${ }^{66}$. Las relaciones entre ambos tronos se mantuvieron y no sólo en el plano epistolar: Ramón Berenguer y la infanta Violante, hijos del rey Justo y hermanos del arzobispo, casaban respectivamente con sus primos Blanca y Felipe, hijos de Felipe I de Tarento (1294-1332). En el funeral de Felipe el dominico Juan

${ }^{64}$ Michalsky 1998; 2000, pp. 61-84; 2004.

${ }^{65}$ Esa fórmula se empleó en tumbas del siglo XIII: cardenal Riccardo Annibaldi (Herklotz 2001, p. 249) o Gilles du Chastellet (Adhémar 1974, vol. I, p. 30).

${ }^{66}$ La muerte 2018, pp. 31-32, doc. 13. 
de Nápoles volvió a reivindicar la santidad del linaje ${ }^{67}$. Su sermón, pronunciado en Santo Domenico Maggiore y ante gran parte de la aristocracia napolitana, insistió sobre el principio de la beata stirps recurriendo al versículo arbor bona fructus bonos facit (Mateo 7, 17) ${ }^{68}$. Este pasaje puede explicar, en el arcosolio tarraconense, el inusual motivo del arco vegetal poblado por múltiples cabecitas.

El arzobispo se implicó en la disquisición iniciada en el siglo XIII alusiva a la visio $D e i^{69}$, a partir de la trasposición cristiana de ciertas posiciones noéticas de Avicena ${ }^{70}$. La polémica deliberaba si, como defendió el Aquinate, el alma ya era capaz de ver a Dios tras la muerte antes de reintegrarse con el cuerpo resucitado (segundo tipo de visio Dei) por poseer potencia visual ${ }^{71}$, aunque el alma se asemeja más a Dios unida al cuerpo $^{72}$. En el marco de la última disputa medieval sobre la importancia ontológica y soteriológica del cuerpo, Juan XXII había expresado en el sermón de Todos los Santos de 1331 su disconformidad con que el alma de los elegidos pudiese alcanzar la visión beatífica antes del Juicio ${ }^{73}$. El papa sostuvo que antes del Dies Irae las almas bienaventuradas deberán contentarse con observar la humanidad de Cristo ${ }^{74}$. Solo tras el Juicio accederán, en cuerpo y alma, a la contemplación de Dios, sin rastro ya de humanidad ${ }^{75}$. Juan XXII solo se retractó de esta opinión en su

${ }^{67}$ Lewis 1981. Los Anjou promocionaron su realeza sagrada en Italia y Hungría: Vauchez 1977; Klaniczay 1990; Lucherini 2018.

${ }^{68}$ D'Avray 1994, pp. 104-105, 122-125 analiza los textos de este dominico como parte de los sermones memoriales de la corte angevina. Michalsky 2004, n. 32; Lucherini 2019.

${ }^{69}$ Guerrico de Saint-Quentin, Guillermo de Auvernia, Tomás de Aquino... Intentando comprender cómo se adquiere la capacidad de "ver" a través del alma, se diferenciaron tres tipos posibles de visio Dei: la terrenal (Moisés o san Pablo), la de los bienaventurados antes del Juicio y la de los Resucitados tras el Juicio. Esta discusión afronta tres cuestiones teológicas capitales para el cristianismo bajomedieval: qué verán los bienaventurados, Cristo o Dios padre; cómo un intelecto puede ver la esencia divina, infinita e increada; cuándo alcanzarán los bienaventurados la visión de Dios. Cf. Trottmann 1995. En De vision Dei in Gloria, obra de referencia en los años 1260, se justifica "de natura medii per quod videmus". Ibidem, p. 153.

${ }^{70}$ Contenson 1957, 1962.

${ }^{71}$ Distinta de la capacidad visionaria, con la que algunos anticipaban la contemplación de Dios. Hahn 2000, 2019.

${ }_{72}$ Aquino, De Potentia Dei, Q. 5, art. 10, pp. 91-95. Cf. Bynum 1995a, p. 266.

${ }^{73}$ Douie 1950; Weakland 1968; Dykmans 1973; Alcoy 2006, p. 97.

${ }^{74}$ Recuperando el interrogante de san Agustín, cuando planteó de qué le serviría a un alma reencontrar su cuerpo en la Resurrección si pudiera disfrutar ya per se de la visión de Dios. Trottmann 1995, pp. 417-418, 453-455. Para el papa solo los elegidos tras el Juicio y los ángeles en todo momento podían contemplar la presencia glorificadora de Cristo. Ibidem, p. 505. En la estela de Dykmans, Alcoy 2018, p.136.

${ }^{75}$ Trottmann 1995, pp. 433, 451. Mientras haya Iglesia y tiempo en la Tierra, Cristo tendrá una dimensión humana -además de divina- en el Cielo. La polémica de la visio Dei tras la muerte individual y antes del Juicio afectaba nuclearmente a la doctrina cristológica tanto como a la eclesiológica. Fundamental, Tabarroni 1992, pp. 144-145. 
lecho de muerte, contra la que se pronunció, entre otros, el dominico Juan de Nápoles $^{76}$. Juan de Aragón participó competentemente en ese debate: a finales de 1332 envió una epístola en la que argumentaba, a la luz de escritos de Gregorio, Agustín o Jerónimo, que las almas de los justos disfrutaban desde el primer instante de la Dei beatifica visione y no solo de la Humanidad de Cristo ${ }^{77}$. Para Alcoy esa deliberación sobre la inmediata beatificación de las almas puede advertirse en el Salterio Anglo-Catalán ${ }^{78}$ y en el sepulcro del Patriarca.

Su tío Roberto de Anjou, también en 1332, había enviado al papa un tratado sobre esta cuestión y con idéntica opinión ${ }^{79}$. Sorprende que tío y sobrino coincidieran con los postulados sostenidos por los dominicos, fieles a Aquino, cuando ambos eran proclives en espiritualidad, conducta y oratoria, a los franciscanos ${ }^{80}$, abogados de las tesis de Juan XXII ${ }^{81}$. La controversia se zanjó casi un año y medio después de la muerte del arzobispo. El 29 de enero de 1336 Benedicto XII promulgó la bula Benedictus Deus que resolvía que las almas puras eran capaces de ver la esencia divina nude, clare et aperte antes del Juicio Final como retribución inmediata al alma de los bienaventurados tras la muerte corporal ${ }^{82}$.

Conforme a lo expuesto, la escena del fondo del arcosolio no sería una elevatio animae (fig. 6) ${ }^{83}$. Los dos ángeles, que sostienen un paño cóncavo $^{84}$, han acabado de ascender, se arrodillan y miran a la divinidad. Como bien reconoció Alcoy, el relieve del alma beatífica de don Juan -de hinojos, orante y alzando la vista- ya ve plenamente a Dios ${ }^{85}$. Desde luego,

${ }^{76} \mathrm{Al}$ inicio de su tratado Utrum anime sanctorum separate a corporibus ante resurrectionem generalem videant clare seu aperte vel beatifice divinam essentiam (1332) arguyó que las almas beatíficas aún sin cuerpo ya podían realizar operaciones volitivas y racionales, como ver a Dios. Trottmann 1995, p. 576.

${ }^{77}$ El argumentario en Dykmans 1970a, pp. 154, 156 (invocado por Alcoy 2006, p. 97; 2018, p. 139), pero el análisis más reciente en Trottmann 1995, pp. 691-695, 779-810.

${ }_{78}^{78}$ Alcoy 2006, pp. 98-99.

${ }^{79}$ Dykmans 1970b; Trottmann 1995, pp. 695-697; Boyer 1995; Ot 2001, pp. 16, 42; Alcoy 2018, p.137.

${ }^{80}$ Dykmans 1970b, pp. 34-36; Boyer 2005; Español 2014.

${ }^{81}$ La tumba de Juan XXII, en la catedral de Aviñón, fue severamente dañada durante la Revolución Francesa. Nada sabemos sobre la posible relación entre la iconografía y su aceptación postrera de la Visio Dei.

82 Bynum 1995a, p. 285; Trottmann 1995, pp. 779-787. Cómo se figuró la cuestión en el Omne Bonum (Londres, British Library, Royal ms 6 E VI, f. 16r) en Sandler 1986.

${ }^{83}$ Sí lo es, por partida doble, la del monumento de Elisenda de Moncada; Alcoy 2018, p. 138. En la imagen visible desde el claustro su alma desnuda no mira a Dios. Tampoco lo hacen los ángeles. Así, nada se puede decir sobre la visio Dei en esta obra.

${ }^{84} \mathrm{Cf}$. las tumbas de obispos de Soissons: Gosselin de Vierzy (†1152) o Ansculfo de Pierrefonds ( $† 1158)$. Oxford, Bodleian Library, Gough drawings, Gaignières 13; París, Bibliothèque Nationale de France, ms. Latin 17208, f. 199. Adhémar 1974, vol. I, p. 14.

${ }^{85}$ Alcoy 2007, p. 206; 2017b, p. 98; 2018. 
el Patriarca accede a la Primera Persona y no a la Segunda - puesto que no se representan los estigmas de la Pasión de Cristo, quien reina en el Cielo como Dios y Hombre hasta la Parusía-. La imagen expresó las tesis del patriarca y se acomodó a la bula Benedictus Deus (la beatitud del alma, que es la visión intelectual de Dios, no depende del cuerpo). Ninguna otra tumba hispana explicita de manera tan militante y certera que es factible contemplar al Padre de modo inmediato y con plena intensidad, sin esperar a la resurrección.

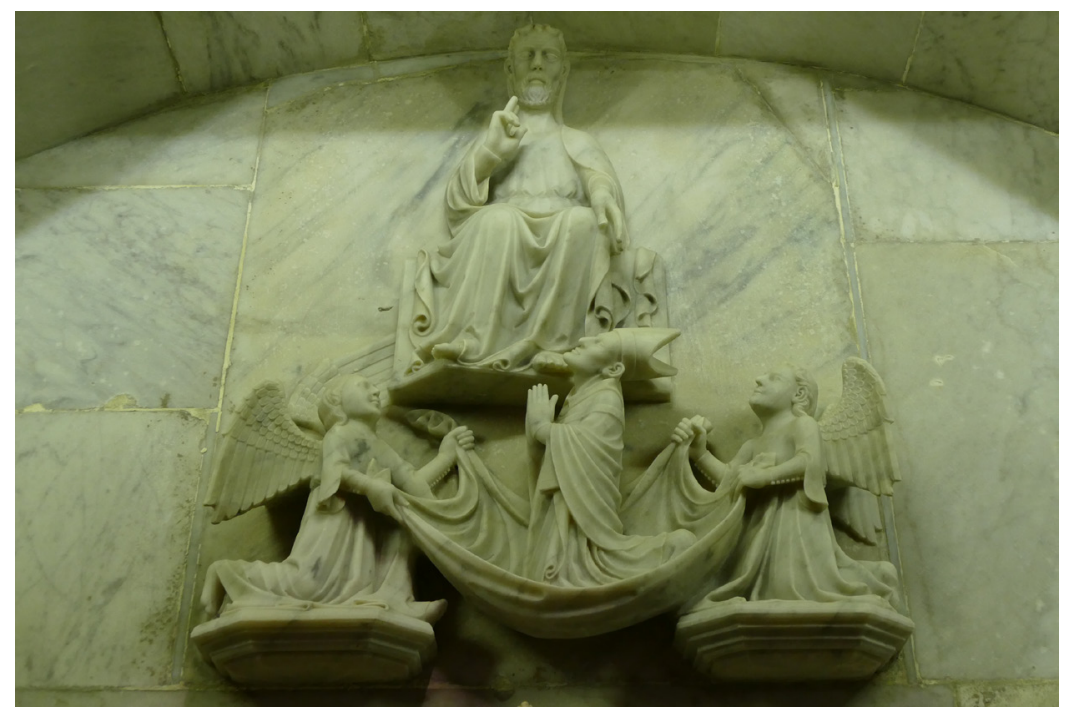

Fig. 6. Detalle del fondo del arcosolio con la Visio Dei. Foto Marta Serrano.

El ideólogo del sepulcro pretendió reforzar los méritos para una plausible -aunque inalcanzada- santificación del patriarca, con la indumentaria como adorno de su virtud, que dijo Durando. La imago del alma porta la especificidad personal -semblante, vestimenta y cargo-, según las tesis del Aquinate. El alma infundirá en la materia del cuerpo restaurado la forma de hombre y de arzobispo, recuperando sus rasgos y atributos. Por esta lógica, las imágenes del alma y la yacente poseen los mismos perfiles.

El rostro explícitamente sonriente del arzobispo (fig. 7) es el de un ser consciente que goza de una mirada interior, restituida por el alma al cuerpo tras la resurrección. A nuestro entender, presenta la apariencia que tendrá don Juan en el Último Juicio, con su cuerpo incólume y el semblante de treinta y tres años, que expondrá en el Cielo, donde ocupará un lugar destacado en el orden episcopal y en su virtuosa estirpe. 


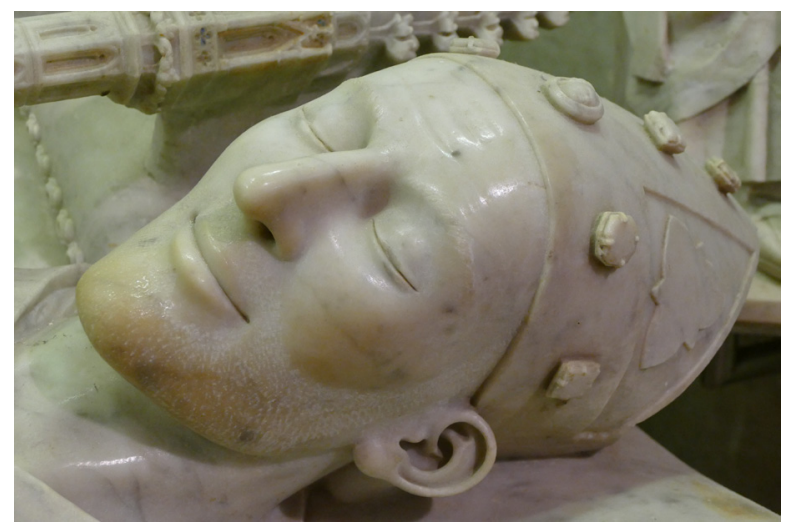

Fig. 7. Detalle del rostro de Juan de Aragón. Foto Marta Serrano.

Juan de Aragón había asumido en 1332 una postura análoga a la del cardenal Pierre Fournier (futuro Benedicto XII), entendiendo que los elegidos disfrutan de la visión beatífica al morir, pero aumenta en intensidad a partir del Juicio. Sin embargo, en 1336 -datación plausible para la tumba- se canonizó la tesis dominica según la cual, tras el Juicio, la visión de los elegidos no aumentará en intensidad, sino en extensión ${ }^{86}$ : en la Gloria definitiva los justos continuarán viendo a Dios con el mismo vigor, pero de modo más completo. En ese campo visual dilatado serán sujeto y objeto de visión beatífica y descubrirán los méritos de los otros santos. En el sepulcro, el cuerpo de don Juan es mirado por los santos de la sede y de su linaje, que refrendan su excelencia moral y avalan su ingreso en el Cielo como meritorio bienaventurado. La disposición de los mártires y confesores en torno al arzobispo se concilia con la doctrina oficial de 1336. El o los autores intelectuales de la sepultura, bien informados de la bula emitida desde Aviñón, configuraron una fórmula suficientemente expresiva y probatoria.

Español ha propuesto que los albaceas fuesen los proyectistas del sepulcro, el más relevante de los cuales sería Sescomes ${ }^{87}$. Protagonista de una trayectoria eclesiástica notable, pero también diplomática en la corte de Jaime II y Pedro IV, se reveló como dinámico promotor ya en la sede de Lérida ${ }^{88}$. Allí había mandado construir la capilla de Jesús, consagrada en 1334 cuando ya había sido confirmado arzobispo de Tarragona ${ }^{89}$; ya advertimos cuánto se asemeja su

${ }^{86}$ Trottmann 1995, pp. 749 y ss.

${ }^{87}$ Español 2019, pp. 153 y ss.

${ }^{88} \mathrm{Su}$ faceta promotora en Ibidem, p. 179. Previamente, Español 1991, pp. 81-82; Alcoy 2003, pp. 71-74.

${ }^{89}$ Conforme a la inscripción, en cuyo marco van dos escudos Sescomes y dos con la Tau de Tarragona. 
fachada a la estructura del sepulcro del patriarca ${ }^{90}$. Su calado político y sensibilidad cultural y literaria -que constata la documentación, sus empresas artísticas y los bienes que acumulóp ${ }^{91}$ - explican la excelencia intelectual, institucional y estética del proyecto funerario de don Juan. Ambos prelados mantuvieron estrechos vínculos a lo largo de su carrera. De hecho, Sescomes fue clave para que Juan XXII concediese nombrar al infante arzobispo de Toledo ${ }^{92}$. No menos revelador resulta el modo en que Sescomes alcanzó la mitra arzobispal tras la muerte de don Juan. A pesar de que el Consell de la ciutat, inspirado por el capítulo catedralicio, había solicitado que se eligiera al pavorde Guerau de Rocabertí, Sescomes se intitulaba arzobispo electe el 11 de septiembre, confirmándolo Juan XXII el 7 de octubre ${ }^{93}$. El pavorde había logrado en septiembre de 1330 permiso de don Juan para erigir la nueva capilla del Corpus Christi, concebida como panteón familiar para enterrar a su tío, el arzobispo Benet de Rocabertí, y a su padre Jofre ${ }^{94}$ en una insólita sepultura que exaltaba el dogma de la transubstanciación ${ }^{95}$. Con la nueva capilla, elaborada conforme a gustos estéticos vanguardistas, Guerau de Rocabertí apuntalaba su ambición de alcanzar la condición de arzobispo, como su tío. La abrupta llegada de Sescomes truncó su aspiración.

Nos parece indudable que Sescomes procuró legitimarse ante un cabildo reacio, iniciando uno de los proyectos artísticos más destacables de aquel momento: el sepulcro de su predecesor, fallecido en olor de santidad, en el que convergieron Iglesia y monarquía ${ }^{96}$. A tenor del documento expedido por Alfonso IV el día después del óbito de su hermano donde solicitaba permiso al cabildo para sepultarlo in loco honorifico tumulentur (...) vos rogamus quatenus coram altari beate Tecle ${ }^{97}$ (nada dice de su asociación a las reliquias, entonces ya en la catedral), creemos que don Juan sería ubicado ante el altar de santa Tecla, en medio del coro, cuyo suelo ya hincaba la sepultura del arzobispo Rodrigo Tello (1288-1308). De esta tumba previa nada sabemos, salvo que no debió de ser eventual: la carta del 12 de diciembre de 1335 del rey Alfonso IV, en la que denuncia el robo del cuerpo del prelado por parte de su hermana Blanca, priora de Sigena, indica que había sido sic honorifice sicque solleniter (...) tumulatum ${ }^{98}$. No puede descartarse que lo hubieran depositado en un sarcófago de mármol,

${ }^{90}$ Serrano, Boto 2018, p. 135.

${ }^{91}$ Rius 1930.

${ }^{92}$ Serra 2016, p. 18.

${ }^{93}$ Ibidem, p. 16.

${ }^{94}$ Morera 1894, p. 122; 1904, p. 148.

${ }^{95}$ Serrano, Boto 2018, pp. 136-137.

${ }^{96}$ Tras un largo período de dificultades, sólo Jaime II y Alfonso IV juraron vasallaje al arzobispo de Tarragona: Bonet, Isla 2011, p. 168.

${ }^{97}$ Vincke 1936, p. 371, ap. 506.

${ }^{98}$ La carta íntegra en Martínez 1948, doc. 459. 
acaso el mismo que durante un siglo contuvo al arzobispo Ramón de Rocabertí (1199-1215) ${ }^{99}$, sito con su rotunda volumetría ante el altar de san Agustín ${ }^{100}$.

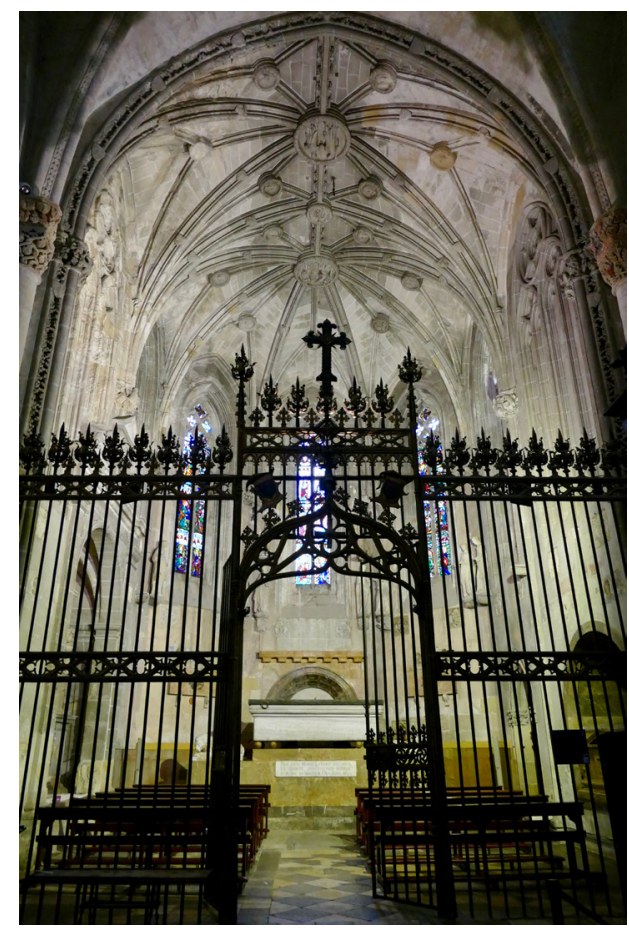

Fig. 8. Capilla de Santa Úrsula y la Once Mil Vírgenes. Catedral de Tarragona, panorámica general. Foto Marta Serrano.

La asociación de don Juan con las reliquias de Tecla se consumó en el monumento $c a$. 1336-1337 $7^{101}$, lo que favoreció espiritualmente al patriarca y contribuyó a la relevancia institucional de la mitra. También el culto Sescomes ${ }^{102}$ asoció reliquias con sus ámbitos funerarios. En 1334 había dotado de multis reliquiis in altari a su capilla funeraria en Lérida, reza un epígrafe. Había obtenido fragmentos del cráneo de santa Úrsula y restos de algunas

${ }^{99}$ En su testamento (01/06/1214) señalaba el encargo. Probablemente era romano reaprovechado y reelaborado. Villanueva 1851, p. 269; Español 2017.

${ }^{100}$ Allí estuvo hasta que la política memorial de Guillem de Rocabertí (1309-1315) homogeneizó los sepulcros en un panteón episcopal en el transepto norte, culminado ca. 1330-1340, acaso ya con Sescomes en la cátedra. Serrano, Boto 2018, p. 126.

${ }^{101}$ Cuando se mencionan las piedras que se desechaban del lugar: Serra 1960, p. 26.

102 Poseía más de cuarenta libros, de Agustín, Boecio, Isidoro, Aquino, Bonaventura, Durando... Rius 1930, pp. 239-241. 
de las Once Mil Vírgenes, primero cedidas a la sede tarraconense, aunque luego depositadas en su capilla funeraria (fig. 8) ${ }^{103}$. Este proyecto espléndido fue erigido hacia 1340, reformulando la tipología arquitectónica de su capilla ilerdense y como aquella junto a una puerta de la catedral. La capilla de santa Úrsula y las Once Mil Vírgenes incrementa las dimensiones, actualiza los recursos tectónicos y desarrolla un ambicioso programa iconográfico en relieves, escultura de bulto, pintura mural y vidrieras.

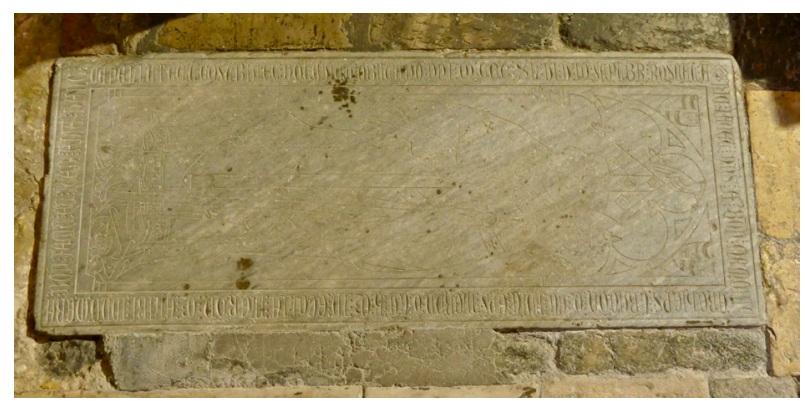

Fig. 9. Lauda sepulcral de Arnau Sescomes. Foto Marta Serrano.

Sescomes fijó su tumba en el epicentro de la capilla (fig. 9) y exigió que fuera rasa -como la de Tello- para evitar el estorbo que suponía un túmulo exento ${ }^{104}$, como el que quizá se encontró en el coro al asumir la sede. Sobre la lauda de caliza se labró su efigie con los pontificalia y una inscripción que proclama: innumera bona fecit, construxit et dotavit ${ }^{105}$. Esta magnanimidad le granjeará, en expectativa, su entrada en el Cielo. Es llamativo que su efigie, aunque muy erosionada, presente los ojos abiertos, según indica el perfil de los ángulos exteriores de sus párpados, rasgo ausente en la lápida de Tello (fig. 10). Su cabeza está enmarcada por un perfil arquitectónico similar a la tracería de los ventanales, epítome de la Jerusalén Celeste y sinécdoque de la propia capilla.

De las tres claves de bóveda (las mayores dedicadas a santa Tecla y san Pablo y a la Coronación de la Virgen; la menor a san Miguel), la que se

\footnotetext{
${ }^{103}$ Las noticias son confusas, pero el episcopologio de Fornés 1645, p. 180 (Paris, Bibliothèque Nationale de France, ms. Baluze 108) señala: "dio este arzobispo [Sescomes] a su iglesia, viviendo, la cabeza de la Virgen Sta. Úrsula, que tenía encastado en plata labrada a marti1lo". Cf. Capdevila 1935 p. 93.

104 "In primis eligo sepulturam meam in capella quam in ipsa eccl. feci ad invocationem et honorem sanctarum undecim milium virginum, que quidem sepultura sit ita plana quod pavimentum dicte capelle non excedat nec impedimentum aliquod ibi prestet. (...) Et prohibeo ut expressius possum quod expense dicte sepulture summam quinquaginta libr. barchinon. inter omnia non excedant". Rius 1930, pp. 233-234; Blanch 1951, vol. II, p. 42.

${ }^{105}$ Inscripción en Morera 1894, p. 80.
} 
localiza encima de la lauda, ante sus ojos, presenta al arcángel psicopompo (fig. 11). Sescomes, informado de las cláusulas de la Benedictus Deus, sabía que tras superar el juicio individual su alma podría ya gozar de la Visio Dei, no plasmada en la iconografía de la capilla conforme a lo conservado. En las claves de los terceletes se multiplican cabezas de las mártires y en los ángulos de la cabecera, dos parejas de Vírgenes, una Anunciación y una Visitación (fig. 12). Así, la tumba del arzobispo se rodeaba tridimensionalmente de María y de santas, que le verían y a quienes vería tras ingresar en el Cielo. La distribución de santos (de la sede y del linaje) en torno a la tumba de don Juan -observado por ellos y expresión del paisaje beatífico que contemplará en la Gloria- se reinterpretó a una escala mayúscula en la capilla de santa Úrsula. También la efigie de Sescomes es objeto y sujeto de visión trascendente en una fábrica elaborada, como pocas, como un espectáculo tangible que prefigura lo intangible y perpetuo.

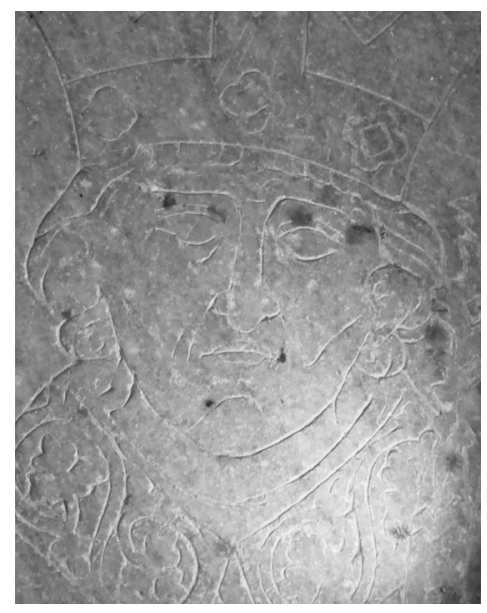

Fig. 10. Detalle del rostro de Arnau Sescomes. Foto Marta Serrano.

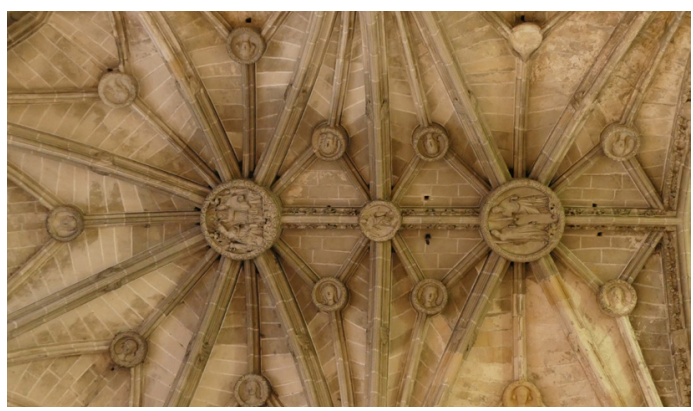

Fig. 11. Bóveda de la capilla de Santa Úrsula y las Once Mil Vírgenes. Foto Marta Serrano. 


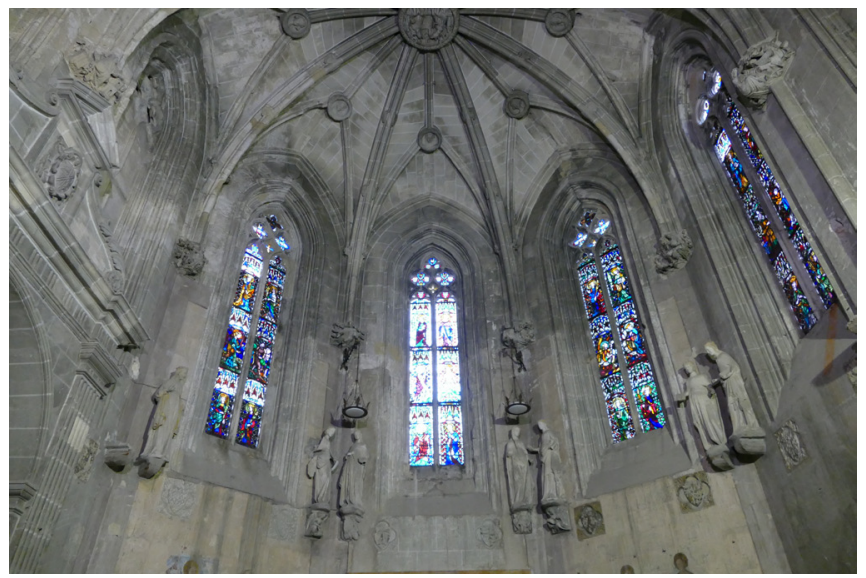

Fig. 12. Cabecera de la capilla de Santa Úrsula y la Once Mil Vírgenes. Foto Marta Serrano.

\section{CONCLUSIÓN}

En el análisis antropológico de la construcción cultural de la visión -del ver y ser visto- y de las imágenes en una sociedad específica, algunas tumbas con yacentes del siglo XIV protagonizaron un episodio singular. Con su doble vertiente retrospectiva y prospectiva, fueron elaboradas como objetos visibles para provecho del finado y de la institución de acogida. También se operaron en sintonía con los debates más candentes sobre la vinculación ontológica y soteriológica del cuerpo y del espíritu. Para los cristianos, la visión trascendente de lo divino comenzaba en la Baja Edad Media, de manera interpuesta, en la contemplación inmanente y sensible de las esculturas de bulto de los prelados, al anticipar la apariencia incorruptible que ofrecerán en el espectáculo panóptico de la Gloria eterna.

La materialidad del sepulcro de don Juan, en su momento el más deslumbrante de la Corona de Aragón junto con los de Santes Creus, contribuye a proclamar su sacralidad, su beatitud y la oficialidad de las nuevas tesis escatológicas que suscribió. La imagen corpórea del alma del Patriarca, encarnada a través de los perfiles tridimensionales de la escultura, constituye el pronóstico de la forma ulterior del cuerpo resucitado, dotado a su vez de una capacidad vidente más extrema y dilatada, conforme a las tesis dominicas. También Sescomes, probable proyectista de la tumba marmórea, quiso ser objeto y sujeto de esta visión trascendente en el espléndido escenario fúnebre que ideó para sí. La expectativa de ambos prelados en relación con sus almas visibles y 
videntes es noesis en estado activo, declaración plástica de la voluntad de lograr la intelección más trascendente e inmediata.

\section{BIBLIOGRAFÍA CITADA}

Adhémar, Jean (1974), Les tombeaux de la collection Gaignières. Dessins d'archéologie du XVII siècle, París, Gazette des Beaux Arts.

Agustín, De Civitate Dei, en Migne, Jacques Paul (ed.) (1864), Patrologia Latina, vol. XLI, Paris, Apud Garnier fratres.

Agustín, De la Piedad con los difuntos, en Obras completas de san Agustín, ed. Teodoro C., vol. XL, Madrid, BAC, 1995, pp. 413-475.

Agustín, Obras completas. II: Las confesiones, ed. Ángel C. Vega, Madrid, BAC, 2019.

Alcoy, Rosa (2003), Els cicles murals de la Seu Vella de Lleida. De les evidències a les reconstruccions ideals, en Seu Vella. L'esplendor retroba$d a$, Lérida, Generalitat de Catalunya, pp. 67-78.

Alcoy, Rosa (2006), Ferrer Bassa y el salterio anglo-catalán, en Morgan, Nigel; Reinhart, Klaus; Alcoy, Rosa, El salterio anglo-catalán, Barcelona, Moleiro, pp. 57-120.

Alcoy, Rosa (2007), Du Corps de Dieu au corps-dieu, en Chateau, Dominique; Parret, Herman; Salabert, Pere (eds.), Esthétiques de la nature, París, Sorbonne, pp. 203-217.

Alcoy, Rosa (2017a), Anticipaciones del Paraíso, Vitoria, Sans Soleil.

Alcoy, Rosa (2017b), San Ludovico de Tolosa e l'immagine del santo vescovo nell'arte catalana (secoli XIV-XV), en Da Ludovico d'Angiò a san Ludovico de Tolosa. I testi e le immagini, Spoleto, Centro di Studi sull'Alto Medioevo, pp. 265-284.

Alcoy, Rosa (2018), El desig del cel. Representacions amb fons epifànic $i$ algunes heterodoxies figuratives dels segles XIII-XV, en Stöber, Karen (ed.), Creences a l'època medieval: ortodòxia i heretgia, Lérida, Pagès, pp. 125-156.

Angheben, Marcello (2013), D'un jugement à l'autre. La représentation du jugement immédiat dans les Jugements derniers français: 11001250, Turnhout, Brepols.

Angheben, Marcello (2020), Le portail central de la Cathédrale de Tarragone et l'évolution du jugement dernier entre le XI' et le XIV siècle, en Español, Francesca; Valero, Joan (eds.), Ianua Coeli. Les portalades gòtiques a la Corona d'Aragó, Barcelona, IEC, pp. 151-178.

Aquino, Tomás de, De Potentia Dei, 5. La conservación, ed. Nicolás Prieto, Pamplona, Universidad de Navarra, 2005. 
Aquino, Tomás de, Opera omnia sive antehac excusa, sive etiam anecdota... t. 20: Commentarii In Epistolam ad Corinthios, ed. Edouard Fretté, París, Vives, 1876.

Avezou, Robert (1930), Un prince aragonais archevêque de Tolède au XIVe siècle, don Juan d'Aragon y Anjou, "Bulletin Hispanique" 32, pp. 326-371.

Avray, David d' (1994), Death and the Prince: Memorial Preaching before 1350, Oxford, University Press.

Bango, Clara (2006), Rodrigo Jiménez de Rada, arzobispo de Toledo, en Bango, Isidro G., La Edad de un Reyno. Las encrucijadas de la corona y la diócesis de Pamplona, vol. I, Pamplona, FCPHN, pp. 231-262.

Baschet, Jérôme (1999), Alma y cuerpo en el occidente medieval: una dualidad dinámica, entre pluralidad y dualismo, en Baschet, Jérôme; Pitarch, Pedro; Ruz, Mario H., Encuentros de almas y cuerpos, entre Europa medieval y mundo mesoamericano, Chiapas, Universidad Autónoma, pp. 41-83.

Baschet, Jérôme (2018), L'humain (et l'institution) comme paradoxe. Le corporel et le spirituel dans l'Occident médiéval, "Revue Des Langues Romanes" 122/1, pp. 53-87.

Baxandall, Michael (1980), The Limewood Sculptors of Renaissance Germany, New Haven, Yale Univ Press.

Bazan, Bernardo C. (1983), La Corporalité selon saint Thomas, "Revue philosophique de Louvain" 81/51, pp. 369-409.

Bertaux, Émile (1906), La sculpture du XIVE siècle en Italie et en Espagne, en Michel, André, Histoire de l'Art, vol. II-2, París, Armand Collin, pp. 652-654.

Bieniak, Magdalena (2010), The Soul-body Problem at Paris ca. 1200-1250: Hugh of St-Cher and His Contemporaries, Lovaina, Leuven University Press.

Blanch, Jeroni (1951), Arxiepiscopologi de la Santa Església Metropolitana i Primada de Tarragona, Tarragona, Diputació.

Bock, Nicolas; Foletti, Ivan; Tomasi, Michele (dirs.) (2014), L'évêque, l'image et la mort. Identité et mémoire au Moyen Âge, Roma, Viella.

Bonet, Maria; Isla, Amancio (2011), Tarragona medieval. Capital eclesiàstica $i$ del Camp, vol. II, Lérida, Pagès.

Boto, Gerardo (2015), Metaphora, mirar la materia para ver lo etéreo. La puerta claustral de la catedral de Tarragona, "Románico" 20, pp. 24-33.

Boto, Gerardo; Serrano, Marta (2018), Acción constructiva y memoria monumental de los arzobispos de Tarragona en los escenarios de la catedral (siglo XIV), en Herráez, María Victoria; Cosmen, María 
Concepción; Teijeira, María Dolores; Morais, José A. (eds.), Obispos y Catedrales. Arte en la Castilla bajomedieval, Berna, Peter Lang, pp. 563-605.

Boyer, Jean-Paul (1995), Ecce rex tuus. Le roi et le royaume dans les sermons de Robert de Naples, "Revue Mabillon" 6 (1995), pp. 101-136.

Boyer, Jean-Paul (2005), Sapientis est ordinare. La monarchie de Sicile-Naples et Thomas d'Aquin (de Charles Irr à Robert), en Cevins, Marie-Madeleine de; Matz, Jean-Michel (dirs.), Formation intellectuelle et culture du clergé dans les territoires angevins (milieu du XIII ${ }^{e}$ - fin $d u X V^{e}$ siècle), Roma, École Française de Rome, pp. 277-312.

Bynum, Caroline W. (1990), Material Continuity, Personal Survival and the Resurrection of the Body: A Scholastic Discussion in Its Medieval and Modern Contexts, "History of Religions" 30/1, pp. 51-85.

Bynum, Caroline W. (1995a), The Resurrection of the Body in Western Christianity, 200-1336, Nueva York, Columbia University Press.

Bynum, Caroline W. (1995b), Why all the fuss about the body? A medievalist's perspective, "Critical inquiry" 22, pp. 1-33.

Bynum, Caroline W. (1998), Death and Resurrection in the Middle Ages: Some Modern Implications, "Proceedings of the American Philosophical Society" 142/4, pp. 589-596.

Callahan, Daniel F. (2016), Jerusalem and the Cross in the Life and Writings of Ademar of Chabannes, Leiden, Brill.

Calvo, Tomás (1958), La teoría hilemórfica de Aristóteles y su proyección en el De Anima, "Logos: Anales del Seminario de Metafísica" 3, pp. 12-25.

Camille, Michael (2000), Before the Gaze: The internal senses and late medieval practices of seeing, en Nelson, Robert (ed.), Visuality Before and Beyond the Renaissance: Seeing as Others Saw, Cambridge, Cambridge University Press, pp. 197-223.

Catalán, Oriol (2021), Ut doceat, ut delectet, ut moveat: the Sermons of John of Aragon, Archbishop of Toledo and Tarragona, "Medieval Sermon Studies", en prensa.

Capdevila, Sanç (1935), La Seu de Tarragona. Notes històriques sobre la construcció, el tresor, els artistes, els capitulars, Barcelona, Balmes.

Chabannes, Adémar de, Chronique, ed. Jules Chabanon, París, Picard, 1897.

Chenu, Marie-Dominique (1950), Introduction à l'étude de Saint Thomas d'Aquin, Montreal, Institut d'Études Médiévales.

Chenu, Marie-Dominique (1959), Saint Thomas d'Aquin et la théologie, París, Seuil.

Chobham, Thomas of, Summa de arte praedicandi, ed. Franco Morenzoni, Turnhout, Brepols, 1988. 
Contenson, Pierre-Marie de (1957), Avicennisme latín et vision de Dieu au début du XIII" siècle, "Archives d'histoire doctrinale et littéraire du Moyen Age" 26, pp. 29-97.

Contenson, Pierre-Marie de (1962), La théologie de la vision de Dieu au début du XIII siècle: Le De retributionibus sanctorum de Guillaume d'Auvergne et la condamnation de 1241, "Revue des Sciences philosophiques et théologiques" 46-3, pp. 409-444.

Cullmann, Oscar (1969), Immortalité de l'âme ou Résurrection des Morts?, en Cullmann, Oscar, Des Sources de L'Evangile à la formation de la théologie chrétienne, Neuchâtel, Delachaux et Niestlé, pp. 159-165.

Denzinger, Heinrich (1911), Enchiridion symbolorum, definitionum, et declarationum de rebus fidei et morum, Friburgo, Clemens Bannwart.

Douie, Decima L. (1950), John XXII and Beatific Vision, "Dominican Studies" 3, pp. 154-174.

Durandus, Guillaume, Rational des divins offices, trad. Charles Barthélemy, París, Louis Vivès, 1854.

Durandus, Guillaume, Rationale Divinorum Officiorum, ed. Anselme Davril, Timothy M. Thibodeau, Turnhout, Brepols, 1995.

Dykmans, Marc (1970a), Lettre de Jean d'Aragon, patriarche d'Alexandrie, au pape Jean XXII sur la vision béatifique, "Analecta Sacra Tarraconensia" 42, pp. 143-168.

Dykmans, Marc (ed.) (1970b), Robert d'Anjou. La Vision bienheureuse, traité envoyé au pape Jean XXII, Roma, Gregoriana.

Dykmans, Marc (ed.) (1973), Les sermons de Jean XXII sur la vision béatifique, Roma, Gregoriana.

Español, Francesca (1991), La Seu Vella: els seus promotors, en La Seu Vella de Lleida. La catedral, els promotors, els artistes. S. XIII a s. XV, Barcelona, Generalitat, pp. 77-92.

Español, Francesca (2008), La Beata Stirps en la Corona de Aragón. Santa Isabel de Hungría y San Luis de Tolosa, culto e iconografía, en Español, Francesca; Fité, Francesc (eds.), Hagiografia peninsular en els segles medievals, Lérida, Universitat de Lleida, pp. 135-168.

Español, Francesca (2014), Formas artísticas y espiritualidad. El horizonte franciscano de Jaime II y su círculo familiar, en Beceiro, Isabel (dir.), Poder, piedad y devoción. Castilla y su entorno. Siglos XII-XV, Madrid, Sílex, pp. 389-422.

Español, Francesca (2017), Nobleses de pedra qui facen per nos. Marbre de pedrera $i$ episodis de spolia a les empreses artístiques medievals de l'orient peninsular, en Giráldez, Pilar; Vendrell, Marius (coords.), Bella pedra vella. Explotació, usos i conservació en l'àmbit de la Corona d'Aragó, Barcelona, Patrimoni 2.0, pp. 131-148. 
Español, Francesca (2019), El sepulcre de Joan d'Aragó a la catedral de Tarragona. Un aixopluc de marbre en el context de la beata stirps, "Lambard" 27, pp. 153-186.

Eugyppius, Theasaurus ex S. Agustini Operibus, en Migne, Jacques Paul (ed.) (1863), Patrologia Latina, vol. LXII, París, Apud Garnier fratres, col. 561-1166.

Fornés, Fernando (1645), Episcopologio universal del arzobispado de Tarragona, Tarragona, manuscrito.

Givens, Jean A. (2005), Observation and Image-Making in Gothic Art, Nueva York, New York University Press.

Greshake, Gisbert; Kremer, Jacob (1986), Resurrectio mortuorum: Zum theologischen Verständnis der leiblichen Auferstehung, Darmstadt, Wissenschaftliche Buchgesellschaft.

Hahn, Cynthia (2000), Visio Dei. Changes in Medieval Visuality, en Nelson, Robert (ed.), Visuality Before and Beyond the Renaissance: Seeing as Others Saw, Cambridge, Cambridge University Press, pp. 169-196.

Hahn, Cynthia (2019), Vision, en Rudolf, Conrad (ed.), A Companion to Medieval Art. Romanesque and Gothic in Northern Europe, Blackwell, Hoboken, pp. 71-93.

Hassig, Debra (1991), He Will Make Alive Your Mortal Bodies: Cluniac Spirituality and the Tomb of Alfonso Ansúrez, "Gesta" 30/2, pp. 140-153.

Heinzmann, Richard (1965), Die Unsterblichkeit der Seele und die Auferstehungd es Leibes: Eine problemgeschichtliche Untersuchungd der frühscholastischen Sentenzen- und Summenliteratur von Anselm von Laon bis Wilhelm von Auxerre, Munster, Aschendorff.

Herklotz, Ingo (2001), Sepulcra e Monumenta nel Medioevo, Nápoles, Liguori.

Horowski, Aleksander (2017), Ludovico nei sermoni di Giovanni d'Aragona e di Antonio di Spagna, en Da Ludovico d'Angiò a san Ludovico di Tolosa. I testi e le immagini, Spoleto, Centro di Studi sull'Alto Medioevo, pp. 199-220.

Janer, Ignacio de (1904), El patriarca D. Juan de Aragón, su vida y sus obras, 1301-1334, discurso ante la sociedad Arqueológica de Tarragona, "Boletín Arqueológico" 4/14, pp. 301-376.

Juncosa, Eduard (2015), Estructura y dinámicas de poder en el señorio de Tarragona. Creación y evolución de un dominio compartido (ca. 11181462), Barcelona, CSIC.

Klaniczay, Gábor (1990), Le culte des saints dynastiques en Europe Central (Angevins et Luxembourg au XIV siècle), en L'Eglise et le peuple chrétien dans les pays de l'Europe du Centre-Est et du Nord (XIV $X V^{e}$ siècles), Roma, École Française de Rome, pp. 217-243. 
Klein, Robert (1980), La forma y lo inteligible, Madrid, Taurus.

Kosmer, Ellen (1975), The 'noyous humoure of lecherie', "The Art Bulletin" 57/1, pp. 1-8.

La Figuration des morts dans la chrétienté médiévale jusqu'à la fin du $1^{e r}$ quart du XIV siècle (1989), Fontevraud, Centre Culturel de l'Ouest.

La muerte en la Casa Real de Aragón. Cartas de condolencia y anunciadoras de fallecimientos (siglos XIII al XVI) (2018), Zaragoza, Institución Fernando el Católico.

Las Siete Partidas del rey don Alfonso el Sabio, cotejadas con varios códices antiguos por la Real Academia de la Historia, vol. I, Madrid, Imprenta Real, 1807.

Lewis, Andrew W. (1981), Royal Succession in Capetian France. Studies in Familial Order and the State, Cambridge, Cambridge University Press.

Lucherini, Vinni (2015), Il 'testamento' di Maria d'Ungheria a Napoli: un esempio di acculturazione regale, en Brilli, Elisa; Fenelli, Laura; Wolf, Gerhard (eds.), Images and Words in Exile. Avignon and Italy during the First Half of the $14^{\text {th }}$ Century, Florencia, Sismel, pp. 433450.

Lucherini, Vinni (2018), The Artistic Visualization of the Concept of Kingship in Angevin Hungary, en Barral, Xavier; Lövei, Pál; Lucherini, Vinni; Takács, Imre (eds.), The Art of Medieval Hungary, Roma, Viella, pp. 235-251.

Lucherini, Vinni (2019), Per un approccio storiografico alla monumentalizzazione della morte dei sovrani medievali, "Hortus Artium Medievalium" 25/1, pp. 106-119.

Manote, María Rosa; Terés, María Rosa (1997), El sepulcre de Joan d'Aragó, en L'art gòtic a Catalunya, vol. I, Barcelona, Enciclopèdia Catalana, pp. 126-131.

Marcoux, Robert (2013), L'espace, le monument et l'image du mort au Moyen Âge. Une enquête anthropologique sur les tombeaux médiévaux de la Collection Gaignières, Dijon, Université Laval-Université de Bourgogne (tesis doctoral).

Marcoux, Robert (2016), "Memory, Presence and the Medieval Tomb", en Adams, Ann; Barker, Jessica (eds.), Revisiting the monument. Fifty Years Since Panofsky's Tomb Sculpture, Londres, Courtauld, pp. 49-67.

Marner, Dominic (2000), St. Cuthbert: His life and Cult in Medieval Durham, Londres, British Library.

Martínez Ferrando, Joan E. (1948), Jaime II. Su vida familiar, vol. II, Barcelona, CSIC. 
Martorell, Francisco (1911-1912), Inventari dels béns de la Cambra reyal en temps de Jaume II (1323), "Anuari de l'Institut d'Estudis Catalans" 6, pp. 553-567.

Michalsky, Tanja (1998), Die Repräsentation einer Beata Stirps. Darstellung Ausdruck an den Grabmonumenten der Anjous, en Oexle, Gerhard O.; Von Hülsen, Andrea (eds.), Die Repräsentation der Gruppen: Texte, Bilder, Objekte, Göttingen, Vandenhoeck, pp. 187-224.

Michalsky, Tanja (2000), Memoria und Repräsentation: Die Grabmäler des Königshauses Anjou in Italien, Göttingen, Vandenhoeck.

Michalsky, Tanja (2004), Mater Serenissimi Principis: The tomb of Maria of Hungary, en Elliot Janis; Warr Cordella (eds.), The Church of Santa Maria Donna Regina: Art, Iconography and Patronage in fourteenth-century Naples, Londres, Routledge, pp. 61-77.

Miller, Maureen C. (2014), Clothing the Clergy. Virtue and Power in Medieval Europe (c. 800-1200), Ithaca, Cornell Univ Press.

Moralejo, Serafín (1978), La lauda sepulcral de Alfonso Ansúrez (†1093): su lugar en el desarrollo de la escultura románica hispánica y sus relaciones con el arte jaqués, en Primer Coloquio de Arte Aragonés, Teruel, Diputación, pp. 197-218.

Morera, Emili (1894), Tarragona antigua y moderna. Descripción históricoarqueológica de todos sus monumentos y edificios, Tarragona, Arís e Hijo.

Morera, Emili (1904), Memoria o descripción histórico-artística de la santa iglesia catedral de Tarragona desde su fundación hasta nuestros dias, Tarragona, Arís e Hijo.

Moss, Candida R. (2011), Heavenly Healing: Eschatological Cleansing and the Resurrection of the Dead in the Early Church, "Journal of the American Academy of Religion" 79/4, pp. 991-1017.

Munté, José; Tomás, Andrés (1957), Tarragona. La tesis concepcionista, Tarragona, RSAT.

Ot, Guiralt, La vision de Dieu aux multiples formes: quodlibet tenu à Paris en décembre 1333, ed. Christian Trottmann, Paris, L. Vrin, 2001.

Palazzo, Éric (1999), L'évêque et son image. L'illustration du Pontifical au Moyen Age, Turnhout, Brepols.

Panofsky, Erwin (1964), Tomb Sculpture. Its changing Aspects from Ancient Egypt to Bernini, New York, Phaidon.

Paravicini, Agostino (2000), The Pope's Body, Chicago, Chicago University Press.

Paravicini, Agostino (2003), Edades de la vida, en Le Goff, Jacques; Schmitt, Jean-Claude (eds.), Diccionario razonado del Occidente medieval, Madrid, Akal, pp. 243-252. 
Pereda, Felipe (2001), El cuerpo muerto del rey Juan II, Gil de Siloé y la imaginación escatológica, "Anuario del Departamento de Historia y Teoría del Arte" 13, pp. 53-85.

Previtali, Giovanni (1991), Il sepolcro di Giovanni d'Aragona: un suggerimento, en Studi sulla scultura gotica in Italia, Turín, Einaudi, pp. 93-99.

Quinn, Patrick (1993), Aquinas's Concept of the Body and Out of Body Situations, "Heythrop Journal" 34, pp. 387-400.

Ribot, Josep A. (1729) Camino a la perfección christiana: por el medio de las mas importantes máximas de virtud, Barcelona, Maria Marti.

Risco, Alberto (1926), Algo sobre el infante Juan de Aragón y por qué renunció al Arzobispado de Toledo, "Razón y Fe" 77, pp. 22-31.

Rius, Josep (1930), L'inventari dels béns d'Arnau Cescomes, arquebisbe de Tarragona, "Estudis Universitaris Catalans" 15/2, pp. 231-249.

Rivera, Juan F. (1969), Los arzobispos de Toledo en la baja Edad Media (siglos XII-XV), Toledo, Diputación.

Sánchez Ameijeiras, Rocío (2000), Monumenta et memoriae: the thirteenthcentury episcopal pantheon of León Cathedral, en Valdez, Elizabeth; Pendergast, Carol (eds.), Memory and the Medieval Tomb, Aldershot, Ashgate, pp. 269-299.

Sánchez Real, José (1954) El Archiepiscopologio de Luis Pons de Icart, Tarragona, RSAT.

Sánchez Real, José (1955), La luminaria del Oficio de Tinieblas en la Catedral de Tarragona, "Semana Santa" s/n, s/p.

Sànchez, Jaume F. (2016), Mestre Joan de Tarragona: hipòtesi sobre la seva obra general i la seva producció a la Conca de Barberà (segle XIV), "Aplec de Treballs (Montblanch)" 34, pp. 169-185.

Sandler, Lucy Freeman (1986), Face to Face to God: A Pictorial Image of the Beatific Vision, en Ormrod, William Mark (ed.), England in the Fourteenth Century, Woodbridge, Boydell and Brewer, pp. 224-235.

Santaulària, Joan (1985), Breus apunts biogràfics d'Arnau Ces Comes, "L'Erol. Revista Cultural del Berguedà" 14, pp. 13-17.

Schmitt, Jean-Claude (2009), Par-delà le texte et l'image. Le paradigme céleste de la procession, en Wetzel, René; Flückiger, Fabrice (dirs.), Au-delà de l'illustration. Texte et image au Moyen, approches méthodologiques et pratiques, Zúrich, Chronos, pp. 41-60.

Serra, Rosa (2016), Arnau Sescomes: rellevància político-religiosa i mecenatge artístic a la Catalunya del s. XIV, "L'Erol. Revista Cultural del Berguedà" 127, pp. 15-25.

Serra Vilaró, Joan (1960), El frontispicio de la catedral de Tarragona, Tarragona, Instituto de Estudios Tarraconenses Ramón Berenguer IV. 
Serrano, Marta (2018), Tarragona y la romanidad de su comunidad catedralicia en la Edad Media, "Ars Longa" 7, pp. 71-100.

Serrano, Marta; Boto, Gerardo (2018), Memoria per corporis sensum combibit anima. Un relato histórico en la catedral de Tarragona: presencia y secuencia de ámbitos funerarios arzobispales, "Codex Aquilarensis" 34, pp. 115-142.

Sicard, Damien (1978), La liturgie de la mort dans l'Église latine des origines à la réforme carolingienne, Münster, Aschendorff.

Suter, Roland (1965), El concepto del tiempo según san Agustín, con algunos comentarios criticos de Wittgenstein, “Convivium” 19-20, pp. 97-111.

Tabarroni, Andrea (1992), 'Visio beatifica'e 'Regnum Christi' nell'escatologia di Giovanni XXII, en Ruggieri, Giuseppe (ed.), La cattura della fine. Variazioni dell'escatologia in regime di cristianità, Roma, Marietti, pp. 123-149.

Tomás, Andrés (1960-1961), El culto a san Fructuoso en la catedral de Tarragona. Notas sobre su primitivo altar, "Butlletí Arqueològic" 60-61, pp. 37-64.

Tomás, Andrés (1963), El culto y la liturgia en la Catedral de Tarragona (1300-1700), Tarragona, Instituto de Estudios Tarraconenses Ramón Berenguer IV.

Torija, Enrique (2012), De Aragón a la cátedra de San Ildefonso. Los pontificados medievales de los arzobispos de Toledo de origen aragonés, "Aragón en la Edad Media" 23, pp. 273-300.

Treffort, Cécile (2001), Du mort vêtu à la nudité eschatologique (XII ${ }^{e}-X I I I^{e}$ siècles, en Le nu et le vêtu au Moyen Âge: XII'-XIII siècles, Aix-enProvence, PUP, pp. 351-363.

Trottmann, Christian (1995) La vision béatifique: des disputes scolastiques à sa définition par Benoît XII, Roma, École Française de Rome.

Tugwell, Simon (1990), Human Immortality and the Redemption of Death, Londres, Darton Longman \& Todd.

Tummers, Henricus A. (1980), Early Secular Effigies in England: the Thirteenth Century, Leiden, Brill.

Van Eijk, Antonius H. (1974), La Résurrection des morts chez les pères apostoliques, París, Beauchesne.

Vauchez, André (1977), Beata Stirps: Sainteté et lignage en Occident aux XIII' et XIV siècles, en Famille et parenté dans l'Occident Médiéval, Roma, École Française de Rome, pp. 397-406.

Vergote, Antoine (1991), The Body as Understood in Contemporary Thought and Biblical Categories, "Philosophy Today" 35, pp. 93-105

Villanueva, Jaime (1851), Viage Literario a las Iglesias de España. Viage á Barcelona y Tarragona, vol. XIX, Madrid, RAH. 
Villegas, Manuel; Villanueva, María Carmen (2014), Tradiciones sobre los difuntos en San Agustín en El mundo de los difuntos: culto, cofradias y tradiciones, San Lorenzo del Escorial, Ed. Escurialenses, pp. 43-56.

Vincke, Johannes (1930), El trasllat de l'arquebisbe Joan d'Aragó de la Seu de Toledo a la de Tarragona, "Analecta Sacra Tarraconensia" 6, pp. 127-272.

Vincke, Johannes (1936), Documenta selecta mutuas civitatis Arago-Cathalaunicae et ecclesiae relationes illustrantia, Barcelona, Balmes.

Weakland, John E. (1968), Pope John XXII and the Beatific Vision Controversy, "Annuale Medievale" 9, pp. 76-84.

Wicki, Nikolaus (1954), Die Lehre von der himmlischen Seligkeit in der mittelalterlichen Scholastik von Petrus Lombardus bis Thomas von Aquin, Friburgo, Universitätsverlag.

Wortley, John (2001), Death, Judgment, Heaven, and Hell in Byzantine 'Beneficial Tales', "Dumbarton Oaks Papers" 55, pp. 53-69.

Fecha de recepción del artículo: julio 2020

Fecha de aceptación y versión final: marzo 2021 
